\title{
Pigeons, sandgrouse, cuckoos, nightjars, rollers, bee-eaters, kingfishers and swifts in the European fossil avifauna and their osteological characteristics
}

\author{
Jenő (Eugen) KessLER
}

Received: September 12, 2018 - Revised: December 19, 2018 -Accepted: January 10, 2019

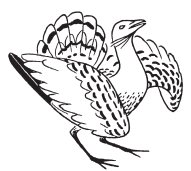

Kessler, J. (E.) 2018. Pigeons, sandgrouse, cuckoos, nightjars, rollers, bee-eaters, kingfishers and swifts in European fossil avifaunas and their osteological characterics. - Ornis Hungarica 27(1): 132-165. DOI: 10.2478/orhu-2019-0009 Columbidae), sandgrouse (Ord. Pteroclidiformes, Fam. Pteroclididae), cuckoos (Ord. Cuculiformes, Fam. Cuculidae), nightjars (Ord. Caprimulgiformes, Fam. Caprimulgidae), rollers (Ord. Coraciiformes, Fam. Coraciidae), bee-eaters (Ord. Coraciiformes, Fam. Meropidae), (Ord. Coraciiformes, Fam. Upupidae), kingfishers (Ord. Coraciiformes, Fam. Alcedinidae) and swifts (Ord. Apodiformes, Fam. Apodidae) in Europe, particularly the Carpathian Basin, during the Tertiary and Quaternary, as well as their osteological characteristics. These orders generally contain a small number of species in Europe, most of them consisting of thermophilic, migratory species. Their fossil and subfossil remains provide precious information about the climatic conditions of their respective areas of origin.

The text is supplemented by 15 figures and 2 tables.

Keywords: Carpathian Basin, Tertiary, Quaternary, avian fauna

Összefoglalás A tanulmányban a szerző bemutatja a galambok, pusztai tyúkok, kakukkok, lappantyúk, szalakóták, gyurgyalagok, jégmadarak és sarlósfecskék jelenlétét a harmad- és negyedidőszak európai, benne a Kárpát-medencei fosszilis madárvilágban, és ismerteti csonttani jellegzetességeiket. A kevés európai fajjal rendelkező rendek többségükben melegkedvelő, vonuló fajokat foglalnak magukban, így maradványaik a lelőhelyeik éghajlatára nézve is értékes információkat szolgáltatnak. Csonttani jellegzetességeik eltérőek.

A szöveget 15 ábra és 2 táblázat egészíti ki.

Kulcsszavak: Kárpát-medence, harmadidőszak, negyedidőszak, madár fauna

Department of Paleontology, Eötvös Loránd University, 1117 Budapest, Pázmány Péter sétány 1/c, Hungary, e-mail: kessler_jeno@yahoo.com

\section{Introduction}

These orders and families are usually represented by merely a few species amongst the European fossilized and recent avian fauna, but are also representative of certain dry land habitats considering their lifestyles, diets and nesting habits.

Most of them are insectivorous, thus are only present as summer guests in Europe, but as such, they provide a reference point regarding climate characteristics of the respective eras to which their remains belong. 
Their skeletal remains are typically easy to distinguish from species of other orders. In the following, we will describe these characteristics, and illustrate them on plates. For every discussed skeletal part, the anatomical terminology (after: Lambrecht 1933, Ballmann 1976, Baumel et al. 1979, Gilbert et al. 1981, Jánossy 1985, Kessler 2013) and method of measurement (von den Driesch 1976, Gál 2002, Kessler 2013) of the bone is given. Arrows indicate the morphological characteristics (Figure 1) and the method of measurement (Figure 2).

According to skeletal parts, their characteristics are the following:

\section{Mandibula (Figure 3)}

a. the tip of the beak is:

- very short: Columba, Streptopelia, Syrhaptes;

- short: Cuculus;

- long: Coracias, Merops;

- very long: Alcedo, Upupa;

b. the recess between the stems is:

- ovoid: Coracias, Syrhaptes;

- ovoid, with recess in the middle: Alcedo, Cuculus, Merops;

- pointed: Columba, Streptopelia, Upupa;

c. the stem is:

- very long: Columba, Streptopelia, Syrhaptes;

- long: Alcedo, Coracias, Merops, Upupa;

- with spur: Cuculus;

\section{Coracoideum (Figure 4)}

a. the processus acrocoracoidalis is:

- rounded: Alcedo, Caprimulgus, Coracias, Upupa;

- hooks: Columba, Merops, Streptopelia, Syrrhaptes;

- cut-off: Apus, Cuculus;

b. the processus procoracoidalis is:

- missing: Caprimulgus;

- mixed with a processus acrocoracoidalis: Alcedo, Upupa;

- long: Cuculus, Syrrhaptes;

- short: Apus, Columba, Coracias, Merops, Streptopelia;

c. the medial end of the sternal part is:

- short and pointed: Upupa;

- long and pointed: Caprimulgus, Merops, Syrrhaptes;

- cut-off and pointed: Alcedo;

- short and rounded: Apus, Cuculus;

- long and rounded: Columba, Coracias, Streptopelia;

d. the lateral end of the sternal part:

- curves downward sharply: Apus, Upupa;

- curves upward: Columba, Coracias, Merops, Streptopelia;

- cut-off straight: Caprimulgus; 
- straight: Cuculus, Syrrhaptes;

- rounded: Alcedo;

\section{Scapula (Figure 5)}

a. the lateral projection is:

- cone-shaped: Apus, Coracias, Merops, Streptopelia;

- rounded: Alcedo, Columba, Upupa;

- cut-off end: Caprimulgus, Cuculus;

b. the dorsal projection is:

- cone-shaped: Apus, Columba, Streptopelia;

- rounded: Caprimulgus, Coracias, Cuculus;

- forked: Alcedo, Merops, Upupa;

\section{Humerus (Figure 6-7)}

a. the crista biccipitalis is:

- rounded: Caprimulgus, Columba, Coracias, Merops, Streptopelia, Upupa;

- cone-shaped: Alcedo, Cuculus, Syrrhaptes;

- cut-off: Apus;

b. the crista pectoralis is:

- rounded: Alcedo, Caprimulgus, Coracias, Cuculus;

- cone-shaped: Merops, Syrhaptes, Upupa;

- curves downward: Columba, Streptopelia;

- cut-off end: Apus;

c. the processus supracondylaris dorsalis is:

- rounded: Caprimulgus, Merops;

- slightly protruding cone shape: Coracias, Cuculus;

- missed: Alcedo, Apus, Columba, Streptopelia, Syrrhaptes, Upupa;

d. the processus flexorius is:

- cone-shaped: Columba, Coracias, Cuculus;

- rounded: Alcedo, Apus, Caprimulgus, Merops, Streptopelia, Upupa, Syrrhaptes;

\section{Ulna (Figure 8-9)}

a. the olecranon is:

- pointed cone: Alcedo, Apus, Caprimulgus, Coracias, Merops, Upupa, Syrrhaptes;

- blunt cone: Columba, Cuculus, Streptopelia;

b. the cotyla dorsalis is:

- blunt cone: Alcedo, Apus, Caprimulgus, Columba, Coracias, Cuculus, Merops, Streptopelia, Syrrhaptes, Upupa;

c. the tuberculum carpale is:

- rounded: Alcedo, Apus, Merops, Streptopelia;

- pointed cone: Syrrhaptes;

- blunt cone: Caprimulgus, Columba, Coracias, Cuculus, Upupa; 


\section{Radius (Figure 10)}

a. the corpus radii is:

- slightly curved: Alcedo, Caprimulgus, Coracias, Merops, Upupa;

- straight: Apus, Columba, Cuculus, Streptopelia, Syrrhaptes;

c. tuberculum aponeurosis ventralis:

- pointening: Apus, Caprimulgus, Cuculus, Upupa;

- blunted: Alcedo, Coracias, Columba, Merops, Streptopelia, Syrrhaptes;

d. tuberculum aponeurosis dorsalis:

- pointening: Upupa;

- with double point: Apus;

- rounded: Alcedo, Columba, Merops, Streptopelia, Syrrhaptes;

- curved: Caprimulgus, Coracias, Cuculus;

\section{Carpometacarpus (Figure 11)}

a. the spatium intermetacarpalis is:

- narrow: Apus;

- large: Columba, Streptopelia, Syrrhaptes;

- very broad: Cuculus, Upupa;

- medium wide: Alcedo, Caprimulgus, Coracias, Merops;

b. the facies articularis digiti major is:

- straight: Apus, Caprimulgus, Syrrhaptes;

- oblique cone shaped: Columba, Coracias, Cuculus, Streptopelia, Upupa;

- with protruding end: Alcedo, Merops;

c. the distal end of the metacarpus major is:

- pointed cone shape: Apus;

- blunt cone: Caprimulgus, Columba, Cuculus, Streptopelia, Syrrhaptes;

- rounded: Alcedo, Coracias, Merops, Upupa;

8. Phalanx proximalis digiti majoris (Figure 12)

a. the proximal end is:

- wavy: Alcedo;

- straight: Merops, Upupa;

- rounded: Apus, Caprimulgus;

- oblique: Columba, Coracias, Cuculus, Streptopelia, Syrrhaptes;

b. the distal end is:

- rounded: Cuculus, Merops;

- protruding: Alcedo, Apus, Columba, Caprimulgus, Coracias, Streptopelia, Syrrhaptes;

- protruding dorsal: Upupa;

c. the dorsal side is:

- rounded: Caprimulgus, Columba, Coracias, Merops, Streptopelia, Syrrhaptes;

- wavy: Alcedo, Cuculus;

- straight: Upupa;

- oblique: Apus; 


\section{Femur (Figure 13)}

a. the trochanter femoris is

- protruding: Caprimulgus, Columba, Streptopelia, Syrrhaptes;

- not protruding: Alcedo, Apus, Coracias, Cuculus, Merops, Upupa;

The morphological homogeneity is significant in the case of this skeletal part.

\section{Tibiotarsus (Figure 14)}

a. the crista fibularis is:

- well-developed: Alcedo, Apus, Columba, Coracias, Streptopelia, Upupa;

- undeveloped: Caprimulgus, Cuculus, Merops, Syrrhaptes;

b. the incisura intercondylaris is:

- deep: Alcedo, Apus;

- medium developed: Caprimulgus, Columba, Coracias, Cuculus, Streptopelia, Syrrhaptes;

- poorly developed: Merops, Upupa;

Homogeneity is significant in the case of this skeletal part.

\section{Tarsometatarsus (Figure 15)}

a. the corpus metatarsi is:

- narrow: Upupa;

- medium thick and straight: Caprimulgus, Columba, Coracias, Cuculus, Streptopelia, Syrrhaptes;

- thick, short and straight: Alcedo, Apus;

- thick and curved: Merops;

b. the trochlea metatarsi II. is:

- pointed: Apus, Cuculus, Merops, Upupa;

- rounded: Alcedo, Caprimulgus, Columba, Coracias, Streptopelia, Syrrhaptes;

c. the trochlea metatarsi III. is:

- protruding: Apus, Merops, Upupa;

- not protruding: Alcedo, Caprimulgus, Columba, Coracias, Cuculus, Streptopelia, Syrrhaptes;

d. the trochlea metatarsi IV. is:

- semicircular: Merops, Streptopelia;

- cone shape: Apus, Syrrhaptes, Upupa;

- protruding: Alcedo, Caprimulgus, Columba, Coracias, Cuculus;

This bone is the most typical skeletal part of these orders. Figure 2. helps understand the size charts (Table 1-2). 


\section{Systematics}

The presence of fossil species in Europe and the occurrence of recent genera and species at sites of the Carpathian Basin and Europe, and symbols for fossilized species from the Carpathian Basin are as follows:

Abbreviations: Q1-Q2 - Lower Pleistocene; Q3 (Q3/I-Q3/II) - Middle Pleistocene; Q4/I - Upper Pleistocene; Q4/II - Holocene; † - extinct/fossil species.

\section{Ord. Columbiformes (Latham, 1790)}

\section{Fam. Columbidae (Illiger, 1811)}

Representatives of the family are only known since the early Miocene across Europe. Their oldest occurrences are Columba omnisanctorum Ballmann, 1976 and C. pisana Portis, 1889 from the early and middle Pliocene of Italy (MN 14-15, MN 15-16) (Portis 1889, Ballmann 1976).

Pigeons are only known on the recent genus level from the Neogene of Europe: Columba sp. from Văršec, Bulgaria and Sandalja, Croatia (MN 17).

\section{- Columba (Linnaeus, 1758)}

\section{- Columba livia (Gmelin, 1789)}

Q1: Beremend 17 (Hungary) (Jánossy 1992, 1996); Q4/I: Velika pec na Lipi (Croatia) (Malez-Bačić 1979, V. Malez 1984,); Q4/II: Legény Cave (Hungary) (Lambrecht 1913); from the Quaternary of Europe: Q1-2: France, Italy; Q3: Azerbaijan, Croatia, France, Georgia, Greece, Russia, Ukraine; Q4: Austria, Bosnia-Herzegovina, Croatia, Czech Republic, France, Georgia, Germany, Greece, Ireland, Italy, Montenegro, Portugal, Russia, Spain, Ukrajne, United Kingdom (Tyrberg 1998).

\section{- Columba palumbus (Linnaeus, 1758)}

MN 16: Betfia 13 (Romania) (Kessler 1975, Gál 2002); Q2: Nagyharsány Hill 1-4 (Hungary) (Lambrecht 1916, 1933, Jánossy 1979a); Q3/I: Hundsheim (Austria) (Jánossy 1971, 1974); Q4/I: Bajót, Baits Cave (Jánossy 1979b); Bajót, Jankovich Cave (Lambrecht 1933, Jánossy 1979a); Budapest, Remetehegy Shelter Cave (Kormos 1914, Lambrecht 1933, Jánossy 1979a, 1986); Cserépfalu, Subalyuk Cave (Jánossy 1979a); Pilisszántó, I. Shelter Cave (Lambrecht 1915, 1933, Jánossy 1979a, 1986); Tatabánya, Szelim Cave (Jánossy 1979a); Varbó, Lambrecht Kálmán Cave (Jánossy 1979a) (all in Hungary); Körösmart (Râpa, Romania) (Jánossy in Hamar \& Csák 1969, Kessler 1974, Gál 2002); Q4/II: Bajcsa Castle (Gál 2002); Balatonkeresztúr, Réti-Dülő (Gál 2007a); Balatonszemes, Bagódomb (Gál 2004, 2007a); Bodajk, Rigólyuk (Kordos 1984); Debrecen, Nyulas (Gál 2007b); Ecsegfalva 23 (Pike-Tay et al. 2004, Gál 2007b); Felsőtárkány, Petényi Cave (Jánossy 1979a); Jósvafö, Musztáng Cave (Kessler 2009); Röszke, Ludvár (Jánossy 1985, Gál 2004, 2007b); Tác, Fövénypuszta (Jánossy 1979a, 1979b); Tác-Gorsium (Bökönyi 1984, Jánossy 1985); Tiszaszőlős, Domaháza-puszta (Gál 2007b); Visegrád Castle (Bökönyi \& Jánossy 1965, Jánossy 1979a (all in Hungary); Parác (Parţa) (Kessler \& Gál 1997, Gál 2004), Remetelórév, Bólyikő Cave (Piatra Boiului) (Kessler 1982); Szegyestel, Drăcoiaia Cave (Sighiștel) (Kessler 1982); Vársonkolyos, Izbîndiş Cave (Şuncuiuṣ) (Kessler 1977, Gál 2002) (all in 
Romania); from the Quaternary of Europe: Q3: Austria, France, Greece, Italy, Spain, United Kingdom; Q4: Austria, Belgium, Czech Republic, France, Georgia, Germany, Greece, Ireland, Italy, Moldova, Montenegro, Poland, Portugal, Romania, Russia, Spain, Switzerland, Ukraine, United Kingdom (Tyrberg 1998).

- Columba oenas (Linnaeus, 1758)

Q4/I: Hollókő (Jánossy \& Vörös 1979, Jánossy 1980); Kőszeg (Lambrecht 1912, 1915, 1933) (all in Hungary); Q4/II: Remetelórév, Bólyikő Cave (Piatra Boiului) (Kessler 1982); Révi Caves (Vadu Crișului) (Kessler 1982) (all in Romania); Teufelslucken (Austria) (Soergel 1966); from the Quaternary of Europe: Q1-2: Greece; Q3: France, Greece, Spain; Q4: Austria, France, Greece, Italy, Russia, Spain, Ukraine, United Kingdom (Tyrberg 1998). - Columba sp. foss. indet.

MN 15: Beremend 26 (Kessler 2010); MN 15: Csarnóta 2 (all in Hungary) (Jánossy 1979a: as Columba livia);

- Columba sp.

Q4/II: Kőrösbánlak Cave (Bălnaca) (Kessler 1982); Révi Caves (Vadu Crisului, all in Romania) (Kessler 1982).

- Streptopelia (Linnaeus, 1758)

- Streptopelia turtur (Linnaeus, 1758)

Q4/II: Legény Cave (Hungary) (Lambrecht 1913); Szegyestel, Drăcoiaia Cave (Sighiștel, Romania) (Kessler 1982); from the Quaternary of Europe: Q3: Italy; Q4: Austria, Czech Republic, France, Italy, Spain, Ukraine (Tyrberg 1998).

- Columbidae gen. et sp. foss. indet.

From the middle Miocene of Mátraszőlős 2 (MN 7/8), it was identified to the family level based on the distal fragment of a tibiotarsus (Kessler \& Hír 2012).

The distal tibiotarsus fragment, that had an abraded condylus, resembles Columbidae in its main characteristics, but differs from recent Columba and Streptopelia genera, and shows more similarities with the latter. Its size reflects this as well.

\section{Fam. Pteroclidae (Bonaparte, 1831)}

Sandgrouse species live in the semi-arid regions of Southern Eurasia and Africa.

Their presence among remains from the Miocene of the Carpathian Basin is somewhat surprising, but they are quite frequently found in the Paleogene and Neogene of the western part of the continent. The bone found in Mátraszőlős may as well come from a migrating specimen.

Their earliest finds come from the Eocene and Oligocene of France (Archaeoganga pinguis Mourer-Chauviré, 1992; A. validus, A. larvatus Milne-Edwards, 1892), as well as the Miocene (Leptoganga sepultus Milne-Edwards, 1892; Gerandia calcaria Milne-Edwards, 1867). They are not known from earlier sediments. Recent species are known since the Quaternary.

- Pteroclidae gen. et sp. foss. indet.

Site and era: The middle Miocene of Mátraszőlös 1 (MN 7/8) identified from a distal phalanx (Kessler 2010).

Typical distal phalanx of a sandgrouse: 
- Syrrhaptes paradoxus (Pallas, 1773)

Q4/I: Pilisszántó I. Shelter Cave (Hungary) (Lambrecht 1915, 1933, Jánossy 1979a, 1986); from the Quaternary of Europe: Q4: Czech Republic (Tyrberg 1998).

- Pterocles alchata (Linnaeus, 1766)

Only Q4: from Italy (Tyrberg 1998).

\section{Ord. Cuculiformes (Wagler, 1830)}

Fam. Cuculidae (Vigors, 1825)

Cuculidae can be found in the temperate and tropical territories of every continent, apart from the Antarctic, in open, grassy areas, among bushes, or trees.

Their earliest appearance is known from the Eocene represented by the species Parvicuculus minor Harrison \& Walker, 1977, described from sites of Burnham-on-Crouch, England (MP 8-9, London Clay) (Harrison \& Walker 1977, Harrison 1982), as well as Condé-en Brie, France (MP 8-9) (Mayr \& Mourer-Chauviré 2005) from tarsometatarsus respectively, as well as from the Eocene and Oligocene of France (Dynamopterus velox Milne-Edwards, 1892; D. boulei Gailard, 1939), the Eocene of the USA (Eocucculus cherpinae Chandler, 1999), this species was also found in the Oligocene of France. Neococcyx mccorguodalei Weigel, 1963 from the Oligocene of France. Veflintopris meini Ballmann, 1969 from the Miocene of Germany. From the Miocene of Hungary Cuculus pannonicus Kessler, 2010 (from the late Miocene of Polgárdi 4 (MN 13) and the late Pliocene of Beremend 15 (MN 16) was described (Kessler 2010), while from the early Pliocene of Csarnóta 2, (MN 15) C. csarnotanus was described (Jánossy 1979b). The latter is smaller than the recent European cuckoo, but is a morphologically identical species, while the former is a new species larger than the recent European cuckoo and differs in several morphological characteristics. Representatives of the family are already present in the middle Miocene of Mátraszőlős I, identified as Cuculidae gent. et sp., from a distal phalanx not identifiable from more recent times (Kessler 2010).

The genus was not found elsewhere in the Neogene of Europe. The recent species is known from the lower Pleistocene of Spain (Quibas, Q1) and Czech Republic (Stránská Skála, Q2) outside of the Carpathian Basin. Materials from the Carpathian Basin is thus unique from this era.

\section{- Cuculus canorus Linnaeus, 758}

Q3/II: Uppony 6 (Hungary) (Jánossy 1979a); Q4/I: Merkenstein (Austria) (Wettstein \& Mühlhofer 1938); Pilisszántó I., Shelter Cave (Lambrecht 1915, 1933, Jánossy 1979a, 1986); Tatabánya, Kálvária Cave nr. 4 (all in Hungary) (Gál 2004, 2005); Q4/II: Szegyestel, Drăcoiaia Cave (Sighiștel, Romania) (Kessler 1982); Teufelslucken (Austria) (Soergel 1966); from the Quaternary outside the Carpathian Basin Q3: Czech Republic, France, Germany; Q4: Austria, Czech Republic, France, Italy, Spain (Tyrberg 1998).

\section{Ord. Caprimulgiformes (Ridgway, 1881)}

Fam. Caprimulgidae (Vigors, 1825)

The order of Caprimulgiformes contains families Steatornithidae, Podargidae, Nyctibiidae, Caprimulgidae and Aegothelidae. They are present on every continent apart from the frigid zones. 
The earliest signs of the Caprimulgidae family come from the Eocene of Great Britain, France, Germany and North America (Eocypselus rowei Klepsa, et al. 2013; Fluvioviridiavis platyrhamphus Mayr and Daniels, 2001 from the USA; Eurofluviridavis robustipes Mayr, 2005, Paraprefica kelleri and P. major Mayr, 1999 from Germany; as well as Archaeotrogon venustus Milne-Edwards, 1892, A. nocturnus Mlíkovský, 2002, Euronyctibius kurochkini Mourer-Chauviré, 1989 and Ventivorus ravei Mourer-Chauviré, 1989 from the Eocene and Oligocene of France), while recent genera are only known from the Quaternary.

\section{- Caprimulgus (Linnaeus, 1758)}

- Caprimulgus europaeus (Linnaeus, 1758) / Caprimulgus † capeki Jánossy, 1977

Site and era: Q1: Betfia 2, 9 (Romania) (Kormos 1913, Čapek 1917, Lambrecht 1933, Kessler 1975, Jánossy 1977, Gál 2002, Mlíkovskỳ 2002); Q4/I: Tatabánya, Kálvária Cave nr. 4 (Hungary) (Gál 2004, 2005);

W. Capek described the subspecies Caprimulgus europaeus $\uparrow$ fossilis from the material gathered by Kormos T., modifyed by Jánossy D. as species C. capeki. The European nightjar is only known from the early Pleistocene of Europe from Stránská Skála, Czech Republic (Q2), and is not too common in the middle and upper Pleistocene either. Q3: France, Italy; Q4: Croatia, Georgia, Italy, Russia, United Kingdom (Tyrberg 1998).

- Caprimulgus ruficollis (Temminck, 1820)

The recent species is known outside the Carpathian Basin: Q3: France; Q4: France (Tyrberg 1998).

\section{Ord. Apodiformes (Peters, 1940)}

Their earliest finds come from the Eocene of Great Britain, Primapus lacki Harrison and Walker, 1975; from the Eocene of Denmark: Scaniacypselus wardi Harrison and Walker, 1984; from the Eocene of Germany: S. szarskii Peters, 1985; Hassiavis laticauda Mayr, 1998; from the Eocene and Oligocene of France: Cypselavus gallicus Gaillard, 1908; Procypseloides ignotus Milne-Edwards, 1871, P. mourerchauvirae Mlíkovský, 2002. Recent genera are present from the Miocene. Apus gailardi Ennouchi, 1930 is known from the Miocene of France, A. wetmorei Ballmann, 1976 from the Pliocene of Italy and Bulgaria, A. baranensis Jánossy, 1977 from the Pliocene of Hungary, while Chaetura baconica Jánossy, 1977 is known from the Miocene of Hungary. Recent species are known since the Quaternary.

\section{Fam. Apodidae Olphe-Galliard, 1887}

- Apus Scopoli, 1777

- Apus † baranensis (Jánossy, 1977 /Apus † wetmorei (Ballmann, 1976)

Site and era: Polgárdi 4, upper Miocene (MN 13) (Kessler 2010); Csarnóta 2, lower Pliocene (MN 15) (Kessler 2010); Beremend 5 (Jánossy 1977); Osztramos 20 (Kessler 2010); upper Pliocen (MN 16) (all in Hungary);

It is a fossil species that has typical characteristics of common swifts, but is smaller than recent species. According to its dimensions, Mlikovskỳ defines it as belonging to the species Apus wetmorei Ballmann, 1976, described from the late Pliocene of Italy. Bones identified from Csarnóta 2 (MN 15), but mainly from Polgárdi (MN 13), indicate an even smaller 
species than in Italy, furthermore they predate it as well. Our opinion is that the two species are not identical.

The genus is only known from the middle Miocene of France in Europe, apart from the Carpathian Basin. Recent species are only known from the early Pleistocene.

- Apus apus (Linnaeus, 1758) / Apus apus † palapus (Jánossy, 1974)

Q2: Kövesvárad (Hungary) (Kessler 2010); Q3/I: Hundsheim (Austria) (Jánossy 1974); Tarkő 1 (Jánossy 1977); Q4/I: Hámor, Puskaporos (Lambrecht 1912, 1916, 1933, Jánossy 1986); Szilvásvárad, Istállóskő Cave (Jánossy 1986); Q4/II: Felsőtárkány, Petényi Cave (Jánossy 1977) (all in Hungary). From outside the Carpathian Basin, Q3: Czech Republic, France, Italy, Russia, Ukraine; Q4: Austria, Bulgaria, Czech Republic, France, Germany, Greece, Italy, Poland, Romania, Russia, Spain, Ukraine, United Kingdom (Tyrberg 1998).

The new subspecies was described by Jánossy from the middle Pleistocene find with dimensions matching that of the recent species, and is probably right to be classified into the recent type.

- Apus melba (Linnaeus, 1758) / Apus $\uparrow$ submelba (Jánossy, 1972)

Q3/I: Tarkő 2, 3, 4 (Jánossy 1972, 1977); Q3/II: Uppony 6 (Jánossy 1977); Q4/I: Cserépfalu, Subalyuk Cave (Jánossy 1977) (all in Hungary); outside the Carpathian Basin Q3: France, Italy; Q4: Bulgaria, France, Georgia, Greece, Poland, Russia, Spain, Ukraine, United Kingdom (Tyrberg 1998).

Jánossy describes the material from Tarkő as a more massive, robust species than the recent one, but their dimensions do not differ significantly from the upper values measured in recent specimens. In the absence of morphological characteristics, Mlikovskỳ (2002) classified it as belonging to the recent species.

- Apus pallidus (Shelley, 1855)

Outside the Carpathian Basin, it is known from the middle Pleistocene (Q3) of France (Tyrberg 1998).

- Chaetura (Stephen, 1826)

- Chaetura † baconica (Jánossy, 1977)

Site and era: Sümeg, Polgárdi 4, upper Miocene (MN 11-12, MN 13) (Jánossy 1977); Beremend 26, lower Pliocene (MN 15) (all in Hungary) (Kessler 2010);

The fossil species is only known from the Carpathian Basin, as well as the genus from across Europe.

Common swifts are migrating, insectivorous birds with rather typical morphology and lifestyle. Other members of the order live in tropical areas. They spend most of their lives airborne, they only land to nest on ledges of cliffs and rock walls. Although they are quite swift fliers, they might fall prey in the daytime to falcons and in the nighttime to owls.

\section{Ord. Coraciiformes (Forbes, 1884)}

Fam. Meropidae (Vigors, 1825)

European bee-eaters are typical migrating birds of warm climates, feeding on hymenopterans. They nest in cavities carved into walls of clay any loess. While they have quite conspicuous feathers and live in groups, thus can relatively easily fall prey to predators, we rarely come across their fossilized remains. 


\section{- Merops (Linnaeus, 1758)}

\section{- Merops † radobojensis (Meyer, 1865)}

Site and era: Radoboj, middle Miocene (MN 7) (Croatia) (von Meyer 1865, Mlíkovskỳ 1997); Rudabánya, upper Miocene (MN 9) (Hungary) (Kessler 2010). It was originally described as Fringilla radobojensis (von Meyer 1865) and Mlikovskỳ redefined it.

- Merops apiaster (Linnaeus, 1758)

Q3/I: Hundsheim (Austria) (Jánossy 1974); the recent species has also been reported from the late Pleistocene (Q4) of France (Tyrberg 1998).

- Merops sp. foss. indet.

Q1: Betfia 9 (Romania) (Gál 2002).

- Meropiidae gen. et sp. foss. indet.

MN 6: Kőalja 2 (Subpiatra 2, Romania) (Kessler \& Venczel 2009).

Fam. Coraciidae (Vigors), 1825

Rollers are insectivorous with conspicuous feathers, due to this they are migrating summer guests, approximately the size of pigeons. They nest on trees, but live in more open areas. Most of the species live in warm climates.

Representatives of other genera of the family are missing from the Neogene of Europe and extinct genera are known from the Eocene of France (Montmartre, Quercy) and Germany (Messel), represented by the taxa Cryptornis antiguus Milne-Edwards, 1871; Geranopterus alatus Milne-Edwards, 1892; G. milneedwardsi Mayr et Mourer-Chauviré, 2000, as well as Eocoracias brachyptera Mayr et Mourer-Chauviré, 2000 (Milne-Edwards 18691871, Mayr \& Mourer-Chauviré 2000, Mlikovskỳ 2002). From the Eocene of USA, Primobucco kistneri Feduccia, 1973; Uintornis lucaris Mars, 1872; Eobucco brodkorbi Feduccia and Martin, 1976 were reported.

\section{- Coracias (Linnaeus, 1758)}

- Coracias garrulus (Linnaeus, 1758)

Q4/II: Ecsegfalva (Hungary) (Pike-Tay et al. 2004, Gál 2007b);

- Eurystomus (Vieillot, 1816)

- Eurystomus $\uparrow$ beremendensis (Kessler, 2010)

Described from the early Pliocene of Beremend 26 (MN 15) (Hungary), based on the proximal segment of a metacarpus and 2 distal phalanges (Beremend, BKAH) (Kessler 2010). It is larger than either the recent species or the find from Betfia.

\section{- Eurystomus sp. foss. indet.}

Q1: Betfia 2, 9 (Romania), (Gál 2002).

Finds differ from characteristics of the recent Coracias garrulus, but match those of the other genus living in Southern Europe and Africa. Fossilized Eurystomus finds are only known from Beremend 26 and Betfia 9, while the recent Coracias garrulus species is only known from the early Pleistocene of Ukraine (Tarchankut, Q1) (Vojinststven'skyj 1967). 


\section{Fam. Upupidae Bonaparte}

Hoopoes also belong to the group of birds mainly widespread in tropical regions. They are summer guests of the Carpathian Basin, feed on insects and larvae, and nest in tree burrows close to the ground. We rarely come across them among fossilized material.

The family only has two extinct species from the Quaternary: Upupa antaios Olson, 1975 from Saint Helena and $U$. phoeniculoides from Austria and Hungary. The recent species is known since the Quaternary.

\section{- Upupa (Linnaeus, 1758)}

\section{- Upupa † phoeniculoides (Jánossy, 1974)}

Site and era: upper Pliocene of Beremend 38 (MN 16) (Hungary) (Kessler 2010); Hundsheim, middle Pleistocene (Q3/I) (Austria) (Jánossy 1974).

The find shows intermediate characteristics between Upupa epops and Phoeniculus purpureus. The newer find from Beremend (Kessler 2010), as well as the fact that the recent species is only known from more current material, just like the genus Upupa (lower Miocene, Czech Republic, MN 3, the find has only been identified to the genus level), both support the validity of the fossilized species.

The genus is known from the upper Miocene of Czech Republic (Upupa sp. - Merkur, MN 3) (Mlikovskỳ 2002), then from the middle Pleistocene of France and Spain.

\section{- Upupa epops (Linnaeus, 1758)}

Q4/II: Kevélynyergi-zsomboly (Hungary) (Kessler 2009). From outside the Carpathian Basin: Q3: France, Spain; Q4: France, Germany, Poland, Spain, Ukraine (Tyrberg 1998).

\section{Fam. Alcedinidae (Vigors, 1825)}

Kingfishers are widespread in the tropical regions.

Recent Halcyon species are only known from the upper Pleistocene of Israel and China from the Palearctic region, while Alcedo atthis is only known from the late Pleistocene of Great Britain, Israel and France. Their earliest known extinct representatives are the Halcyornis toliapicus Koenig, 1825 from the Eocene of England and the Quasisyndactylus longibrachis Mayr, 2004 from the Eocene of Germany, although their classification is debated.

\section{- Halcyon (Swainson, 1821)}

- Halcyon $\uparrow$ sp. foss. indet.

Site and era: Lucsia Cave, middle Pleistocene (Q3/I), (Romania) (Gál 2002);

- Alcedo athis (Linnaeus, 1758)

From Europe outside of the Carpathian Basin it is known from upper Pleistocene sites of France and Great Britain (Tyrberg 1998).

\section{Palaeoecological conclusions}

Representatives of the orders and families listed and discussed are typically rarely found among fossilized material, except for pigeons. One reason for this is that they are not present in large numbers even in the recent fauna, and another is that despite their conspicuously colored feathers, they rarely fall prey to predators, especially to owls, to whom we would 
be able to attribute the accumulation and fossilization of remains due to their pellets. The presented material contains members of two genera that are missing not only from the Carpathian Basin but also most of Europe, apart from the Mediterranean region.

The presence of representatives of the genera Eurystomus, but mainly Halcyon, in the middle Pleistocene of the Carpathian Basin indicates the climate characteristics of the time, which may have been much milder than those of today, especially since the Lucsia Cave is located on the eastern edge of the Transylvanian mountain chain.

\section{Acknowledgements}

The author wishes to express his deep gratitude to Mihály Gasparik for access to the recent bird bone collection in the Natural History Museum of Hungary, to József Vuts and Lóránd Abos for the language revision.

Figure 1. Columba palumbus Linnaeus, 1758 osteology characters:

A. Mandibula - a. the tip of the beak; b. the recess between the stems; $c$. the stem;

B. Coracoideum - a. processus acrocoracoidalis; b. processus procoracoidalis; c. the medial end of the sternal part; $d$. the lateral end of the sternal part;

C. Scapula - a. acromion; b. processus articularis humeralis;

D, E. Humerus - a. crista biccipitalis; b. crista deltopectoralis; c. processus supracondylaris dorsalis;

d. epicondylus ventralis;

F, G. Ulna - a. olecranon; b. apophysis glenoidalis interna; c. tuberculum carpale;

H. Radius - a. corpus radii; b. tuberculum aponeurosis ventrale; c. tuberculum aponeurosis dorsale; I. Carpometacarpus - a. spatium intermetacarpale; b. facies articularis digitalis major; c. the distal end of the metacarpus major;

J. Phalanx proximalis digiti majoris - a. proximal end; b. distal end; c. the dorsal side;

K. Femur - a. trochanter femoris;

L. Tibiotarsus - a. crista fibularis; b. incisura intercondylaris;

M. Tarsometatarsus - a. corpus metatarsi; b. trochlea metatarsi II.; c. trochlea metatarsi III.; d. trochlea metatarsi IV.

1. ábra Columba palumbus Linnaeus, 1758 csonttani jellegek:

A. Alsó állkapocs - a. a csőrhegy jellege; b. a két szár közti mélyedés jellege; c. a szár;

B. Hollócsőrcsont - a. processus acrocoracoidalis; b. processus procoracoidalis; c. a mellcsonti rész mediális vége; $d$. a mellcsonti rész laterális vége;

C. Lapocka - a. acromion; b. processus articularis humeralis;

D, E. Felkarcsont - a. crista biccipitalis; b. crista deltopectoralis; c. processus supracondylaris dorsalis; d. epicondylus ventralis;

F, G. Singcsont - a. olecranon; b. apophysis glenoidalis interna; c. tuberculum carpale;

$\mathrm{H}$. Orsócsont - a. corpus radii; b. tuberculum aponeurosis ventrale; c. tuberculum aponeurosis dorsale;

I. Kézközépcsont - a. spatium intermetacarpale; b. facies articularis digitalis major; c. a metacarpus major disztális vége;

J. A nagy (középső) kézujj első ujjperce - a. proximális vég; b. disztális vég; c. dorsalis oldal;

K. Combcsont - a. trochanter femoris;

L. Lábszárcsont - a. crista fibularis; b. incisura intercondylaris;

M. Csüd - a. corpus metatarsi; b. trochlea metatarsi II.; c. trochlea metatarsi III.; d. trochlea metatarsi IV. 







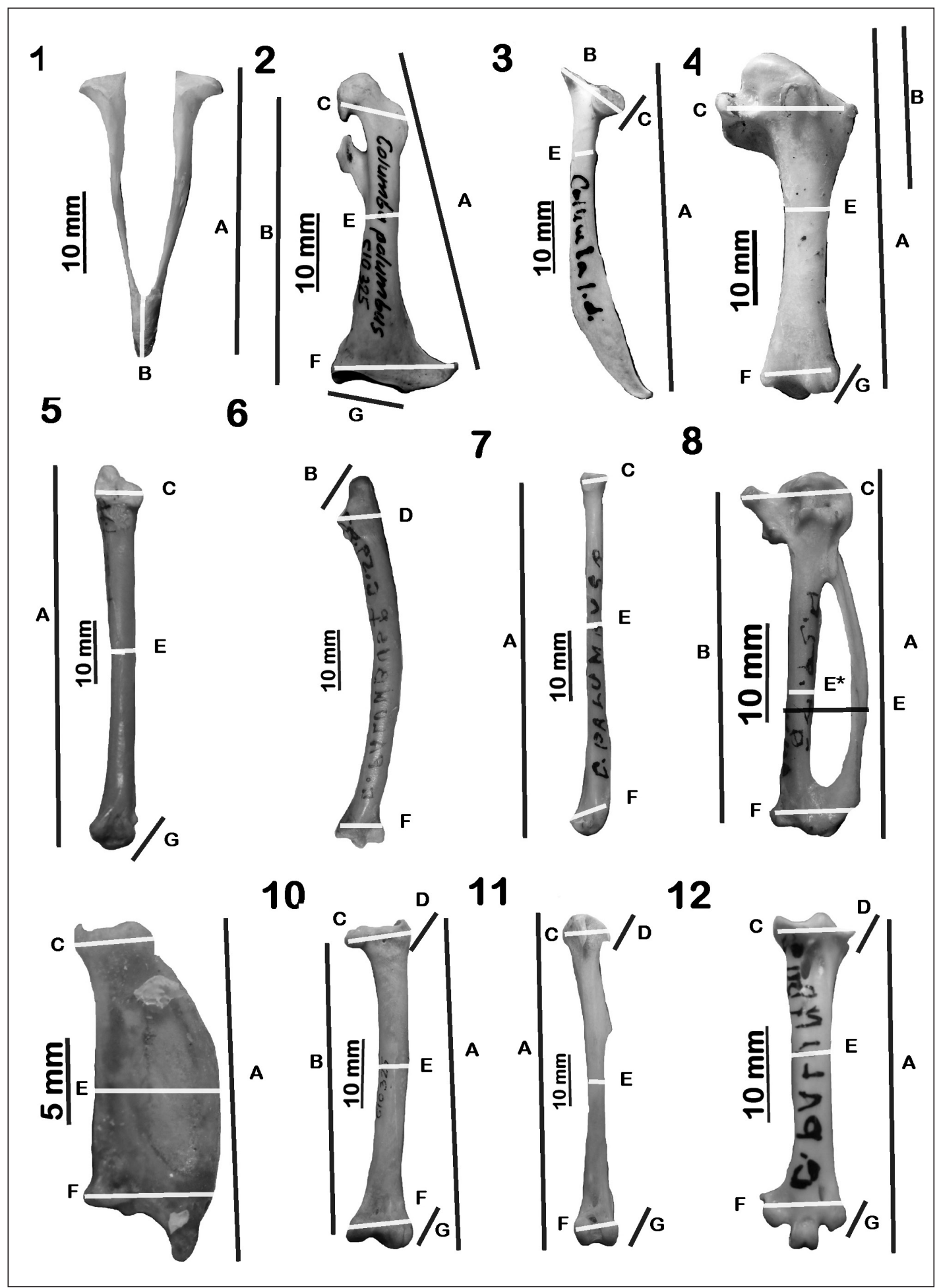


Figure 2. Measurements methods of bones:

1. Mandibula: A. total length; B. partial length (length of apex);

2. Coracoideum: A. total length; B. partial length; C. breadth of the proximal end; E. breadth of the corpus; F. total breadth of the distal end; G. partial breadth of the distal end;

3. Scapula: A. total length; C. breadth of the proximal end; E. breadth of the corpus;

4. Humerus: A. total length; B. partial length; C. breadth of the proximal end; E. breadth of the corpus; F. breadth of the distal end; $G$. thickness of the distal end;

5-6. Ulna: A. total length; B. length of the proximal epiphysis; C. breadth of the proximal end; D. thickness of the proximal end; E. breadth of the corpus; F. breadth of the distal end; G. thickness of the distal end;

7. Radius: A. total length; C. breadth of the proximal end; E. breadth of the corpus; F. breadth of the distal end;

8. Carpometacarpus: A. total length; B. partial length; C. breadth of the proximal end; E. breadth of the corpus; E1: breadth of the metacarpus majus; F. breadth of the distal end;

9. Phalanx proximalis digiti majoris: A. total length; C. breadth of the proximal end; E. breadth of the corpus; F. breadth of the distal end;

10. Femur: A. total length; B. partial length; C. breadth of the proximal end; E. breadth of the corpus; F. breadth of the distal end; $G$. thickness of the distal end;

11. Tibiotarsus: A. total length; $C$. breadth of the proximal end; $D$. thickness of the proximal end; E. breadth of the corpus; F. breadth of the distal end; $G$. thickness of the distal end;

12. Tarsometatarsus: A. total length; C. breadth of the proximal end; D. thickness of the proximal end; $E$. breadth of the corpus; F. breadth of the distal end; $G$. thickness of the distal end

2. ábra A csontok mérési mintái:

1. Alsó állkapocs: A. teljes hossz; B. a csőr hegy hossza;

2. Hollócsőrcsont: A. teljes hossz; B. részleges hossz; C. proximális vég szélessége; $E$. a test szélessége; $F$. a disztális vég szélessége; $G$. a disztális vég vastagsága;

3. Lapockacsont: A. teljes hossz; $B$. részleges hossz; $C$. proximális vég szélessége; $E$. a test szélessége;

4. Felkarcsont: A. teljes hossz; B. részleges hossz; C. proximális vég szélessége; E. a test szélessége; $F$. a disztális vég szélessége; $G$. a disztális vég vastagsága;

5-6. Singcsont: A. teljes hossz; B. részleges hossz; C. proximális vég szélessége; D. proximális vég átlós szélessége; $E$. a test szélessége; $F$. a disztális vég szélessége; $G$. a disztális vég vastagsága;

7. Orsócsont: A. teljes hossz; C. proximális vég szélessége; E. a test szélessége; F. a disztális vég szélessége;

8. Kézközépcsont: A. teljes hossz; B. részleges hossz; C. proximális vég szélessége; E. a test szélessége; E1: a metacarpus majus vastagsága; $F$. a disztális vég szélessége;

9. Kézujjperc (II. ujj, 1. perc): A. teljes hossz; C. proximális vég szélessége; E. a test szélessége; F. a disztális vég szélessége;

10. Combcsont: A. teljes hossz; $B$. részleges hossz; $C$. proximális vég szélessége; $D$. proximális vég vastagsága; $E$. a test szélessége; $F$. a disztális vég szélessége; $G$. a disztális vég vastagsága; 11. Lábszárcsont: A. teljes hossz; C. proximális vég szélessége; D. proximális vég vastagsága; $E$. a test szélessége; $F$. a disztális vég szélessége; $G$. a disztális vég vastagsága;

12. Csüd: A. teljes hossz; C. proximális vég szélessége; $D$. proximális vég vastagsága; $E$. a test szélessége; F. a disztális vég szélessége; $G$. a disztális vég vastagsága 


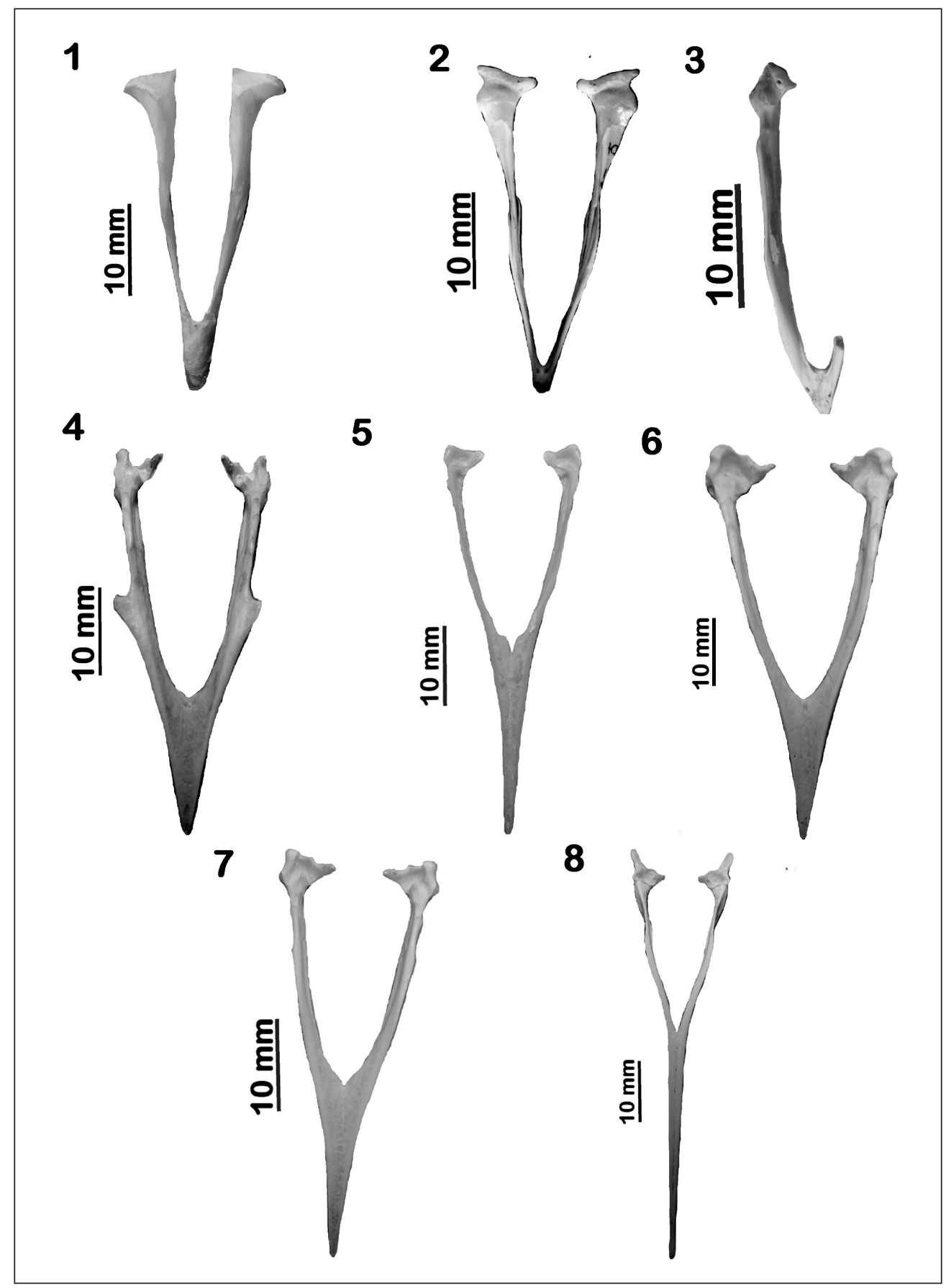

Figure 3. Mandibula - 1. Columba palumbus; 2. Streptopelia turtur; 3. Syrrhaptes paradoxus; 4. Cuculus canorus; 5. Alcedo atthis; 6. Coracias garrulus; 7. Merops apiaster; 8. Upupa epops

3.ábra Alsó állkapocs - 1. Columba palumbus; 2. Streptopelia turtur; 3. Syrrhaptes paradoxus; 4. Cuculus canorus; 5. Alcedo atthis; 6. Coracias garrulus; 7. Merops apiaster; 8. Upupa epops 


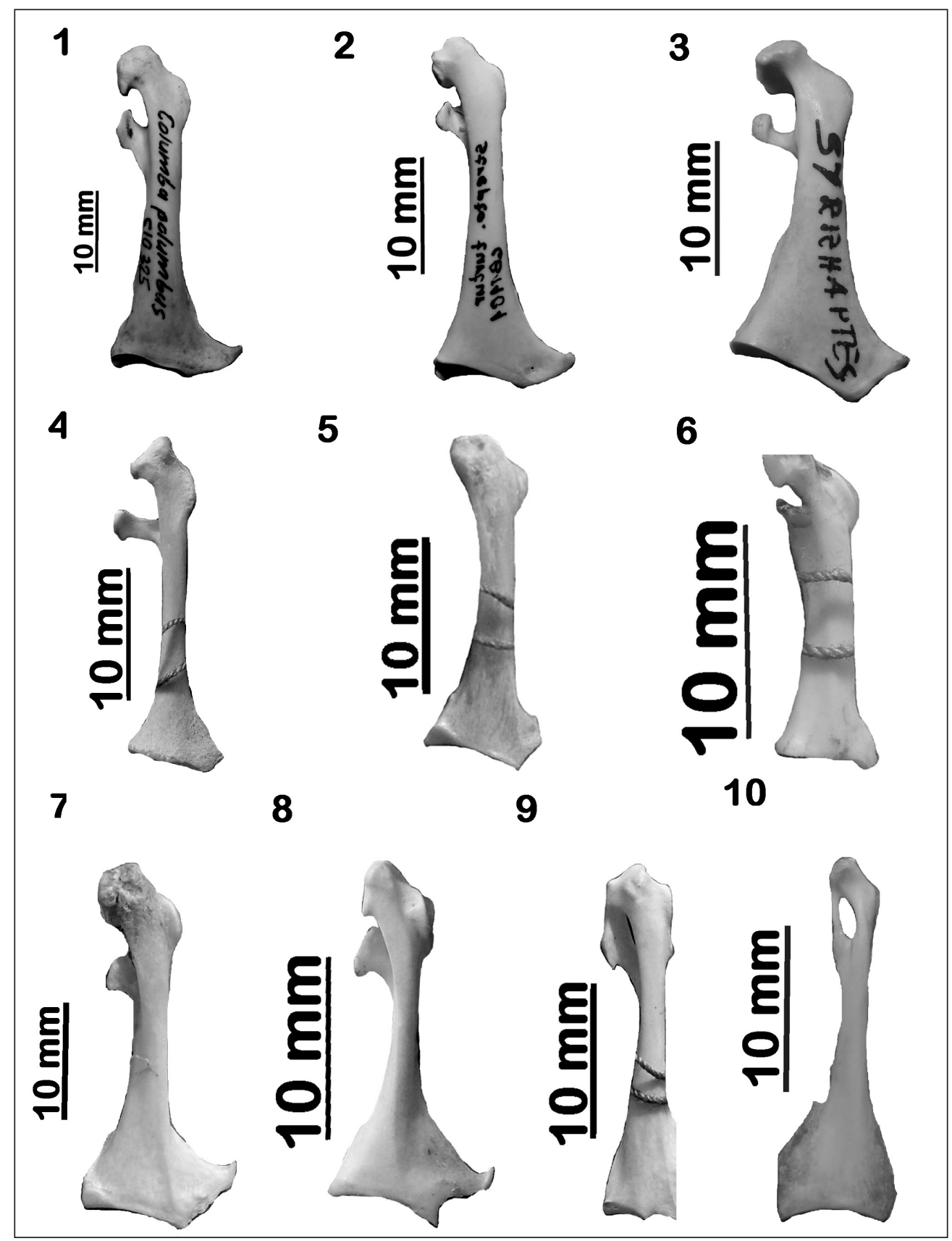

Figure 4. Left coracoideum (ventral surface) - 1. Columba palumbus; 2. Streptopelia turtur; 3. Syrrhaptes paradoxus; 4. Cuculus canorus; 5. Caprimulgus europaeus; 6. Apus apus; 7. Coracias garrulus; 8. Merops apiaster; 9. Upupa epops; 10. Alcedo atthis

4. ábra Bal oldali hollócsőrcsont (hasi oldal) - 1. Columba palumbus; 2. Streptopelia turtur; 3. Syrrhaptes paradoxus; 4. Cuculus canorus; 5. Caprimulgus europaeus; 6. Apus apus; 7. Coracias garrulus; 8. Merops apiaster; 9. Upupa epops; 10. Alcedo atthis 




Figure 5. Right scapula (medial surface) - 1. Columba palumbus; 2. Streptopelia turtur; 3. Cuculus canorus; 4. Caprimulgus europaeus; 5. Apus apus; 6. Coracias garrulus; 7. Merops apiaster; 8. Upupa epops; 9. Alcedo atthis

5. ábra Jobb oldali lapocka csont (mediális oldal) - 1. Columba palumbus; 2. Streptopelia turtur; 3. Cuculus canorus; 4. Caprimulgus europaeus; 5. Apus apus; 6. Coracias garrulus; 7. Merops apiaster; 8. Upupa epops; 9. Alcedo atthis 


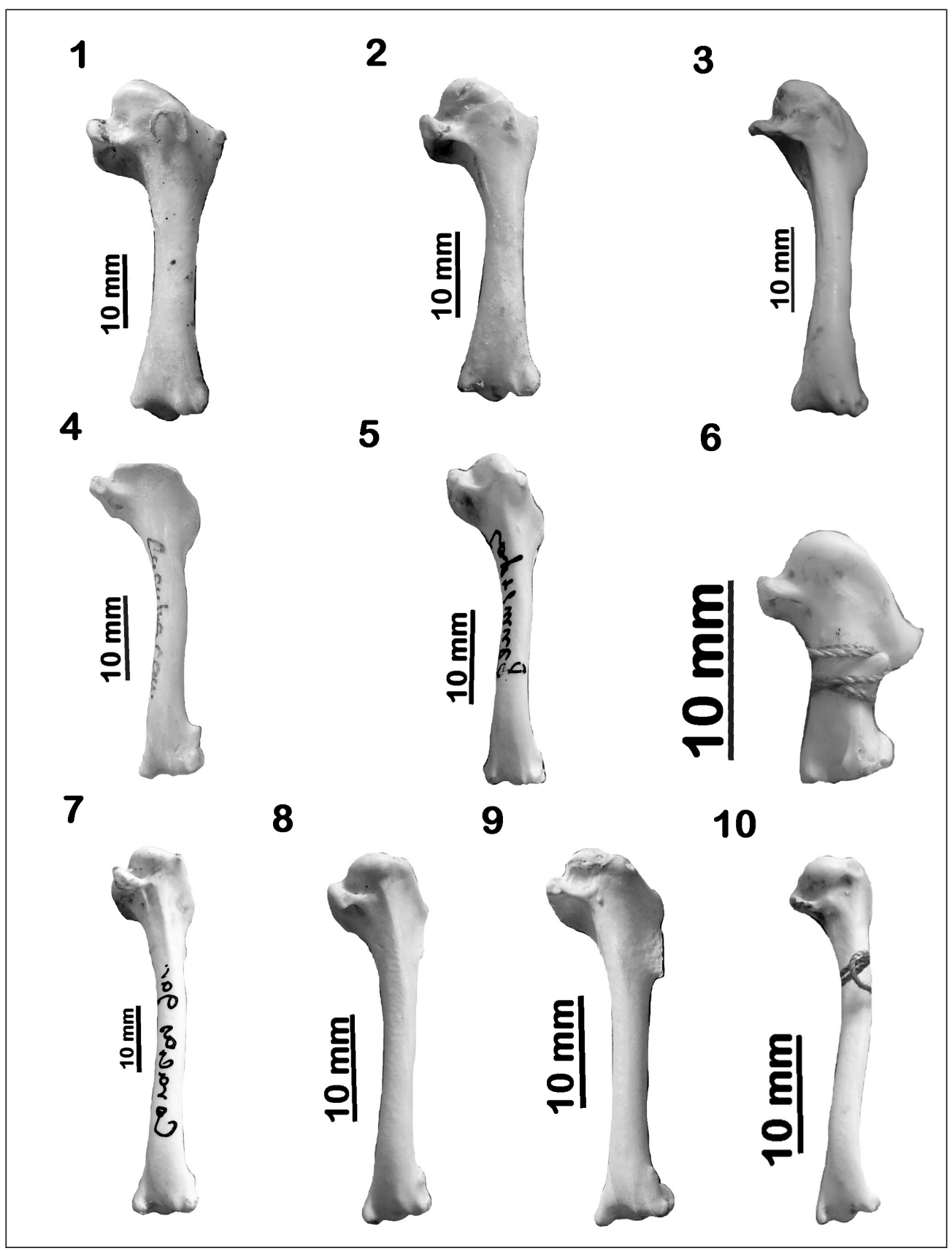

Figure 6. Right humerus (caudal surface) - 1. Columba palumbus; 2. Streptopelia turtur; 3. Syrrhaptes paradoxus; 4. Cuculus canorus; 5. Caprimulgus europaeus; 6. Apus apus; 7. Coracias garrulus; 8. Merops apiaster; 9. Upupa epops; 10. Alcedo atthis

6. ábra Jobb oldali felkarcsont (palmáris oldal) - 1. Columba palumbus; 2. Streptopelia turtur; 3. Syrrhaptes paradoxus; 4. Cuculus canorus; 5. Caprimulgus europaeus; 6. Apus apus; 7. Coracias garrulus; 8. Merops apiaster; 9. Upupa epops; 10. Alcedo atthis 


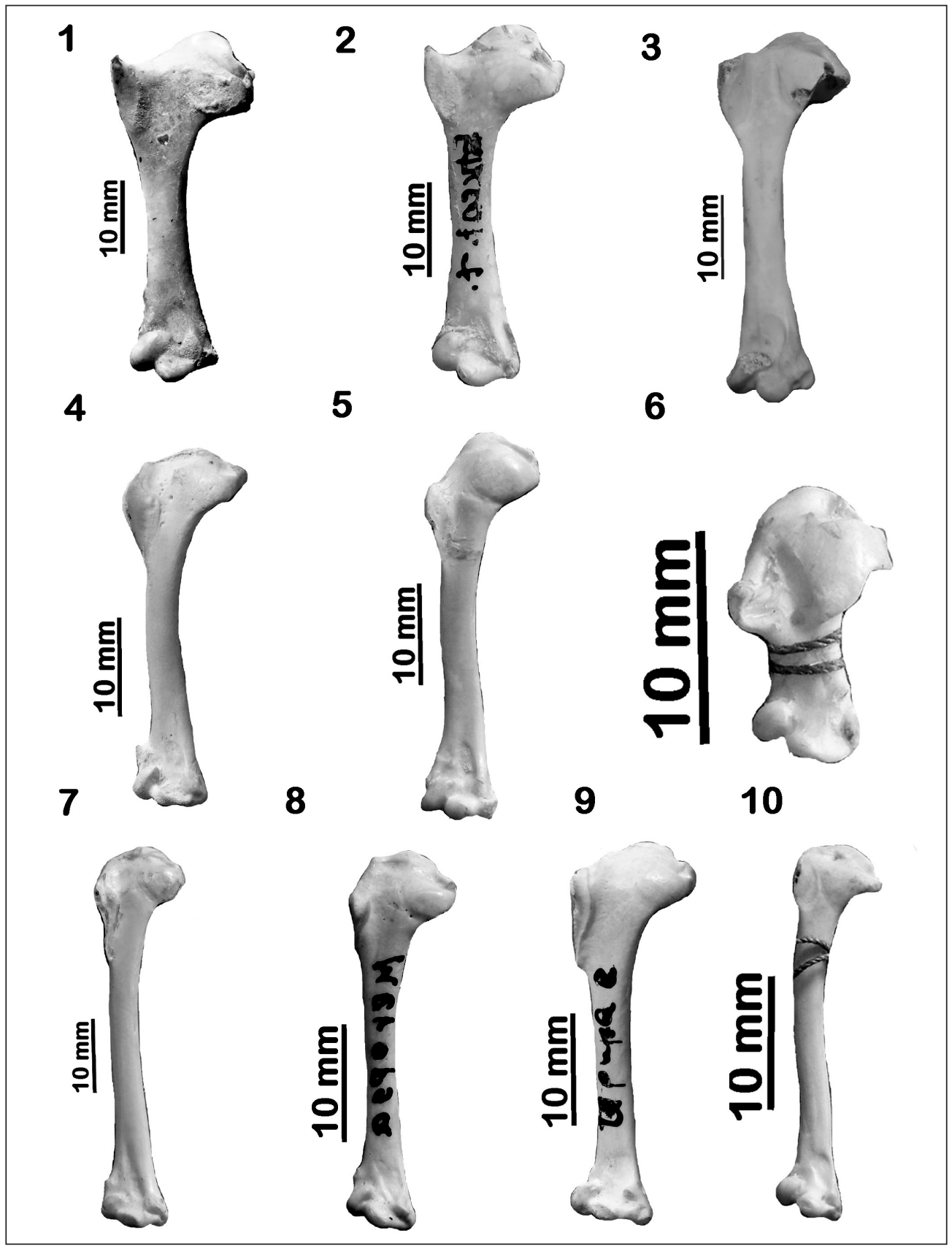

Figure 7. Right humerus (cranial surface) - 1. Columba palumbus; 2. Streptopelia turtur; 3. Syrrhaptes paradoxus; 4. Cuculus canorus; 5. Caprimulgus europaeus; 6. Apus apus; 7. Coracias garrulus; 8. Merops apiaster; 9. Upupa epops; 10. Alcedo atthis

7. ábra Jobb oldali felkarcsont (dorzális oldal) - 1. Columba palumbus; 2. Streptopelia turtur; 3. Syrrhaptes paradoxus; 4. Cuculus canorus; 5. Caprimulgus europaeus; 6. Apus apus; 7. Coracias garrulus; 8. Merops apiaster; 9. Upupa epops; 10. Alcedo atthis 




Figure 8. Left ulna (ventral aspect) - 1. Columba palumbus; 2. Streptopelia turtur; 3. Syrrhaptes paradoxus; 4. Cuculus canorus; 5. Caprimulgus europaeus; 6. Apus apus; 7. Coracias garrulus; 8. Merops apiaster; 9. Upupa epops; 10. Alcedo atthis

8. ábra Bal oldali singcsont (hasi nézet) - 1. Columba palumbus; 2. Streptopelia turtur; 3. Syrrhaptes paradoxus; 4. Cuculus canorus; 5. Caprimulgus europaeus; 6. Apus apus; 7. Coracias garrulus; 8. Merops apiaster; 9. Upupa epops; 10. Alcedo atthis 


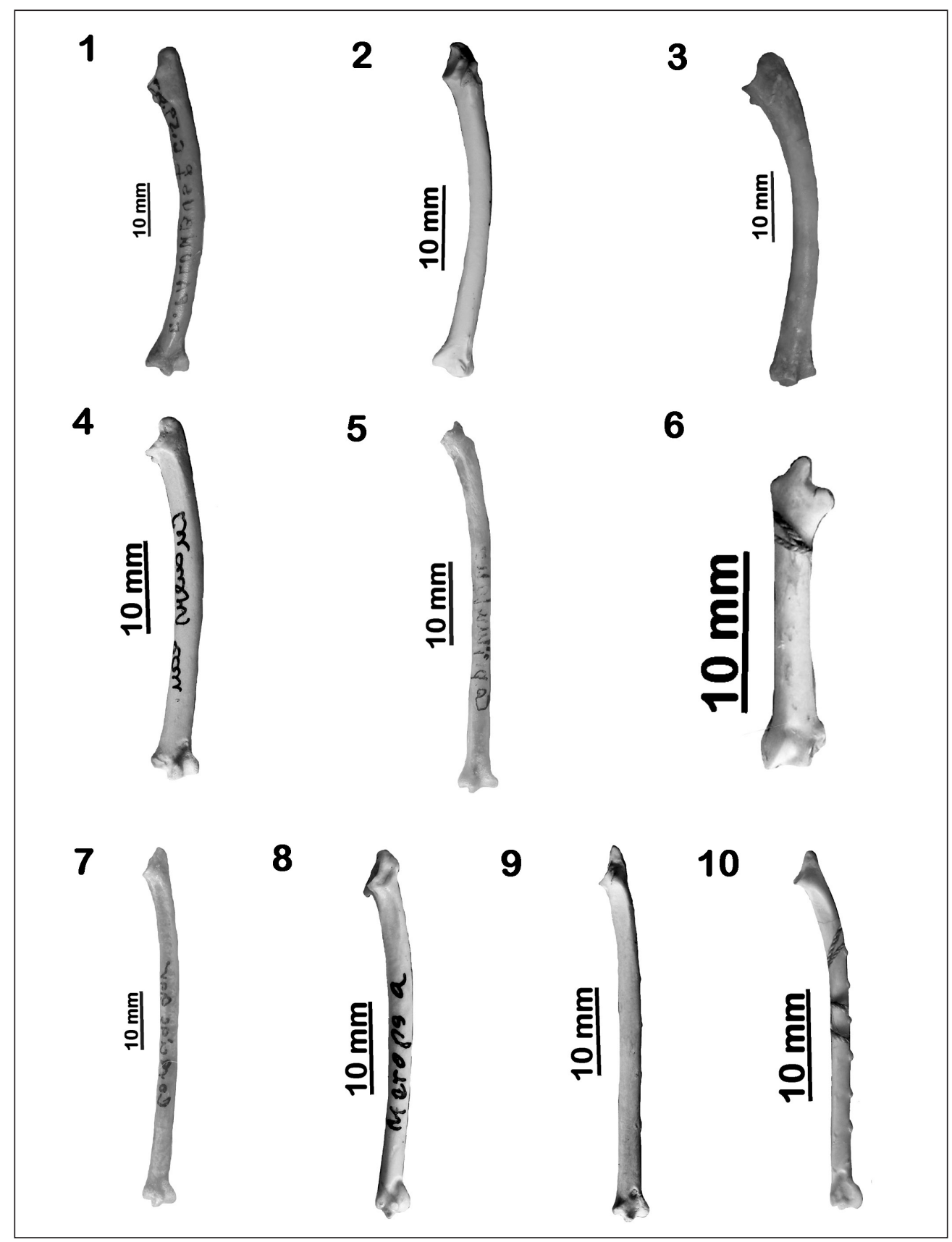

Figure 9. Left ulna (dorsal aspect) - 1. Columba palumbus; 2. Streptopelia turtur; 3. Syrrhaptes paradoxus; 4. Cuculus canorus; 5. Caprimulgus europaeus; 6. Apus apus; 7. Coracias garrulus; 8. Merops apiaster; 9. Upupa epops; 10. Alcedo atthis

9. ábra Bal oldali singcsont (háti nézet) - 1. Columba palumbus; 2. Streptopelia turtur; 3. Syrrhaptes paradoxus; 4. Cuculus canorus; 5. Caprimulgus europaeus; 6. Apus apus; 7. Coracias garrulus; 8. Merops apiaster; 9. Upupa epops; 10. Alcedo atthis 


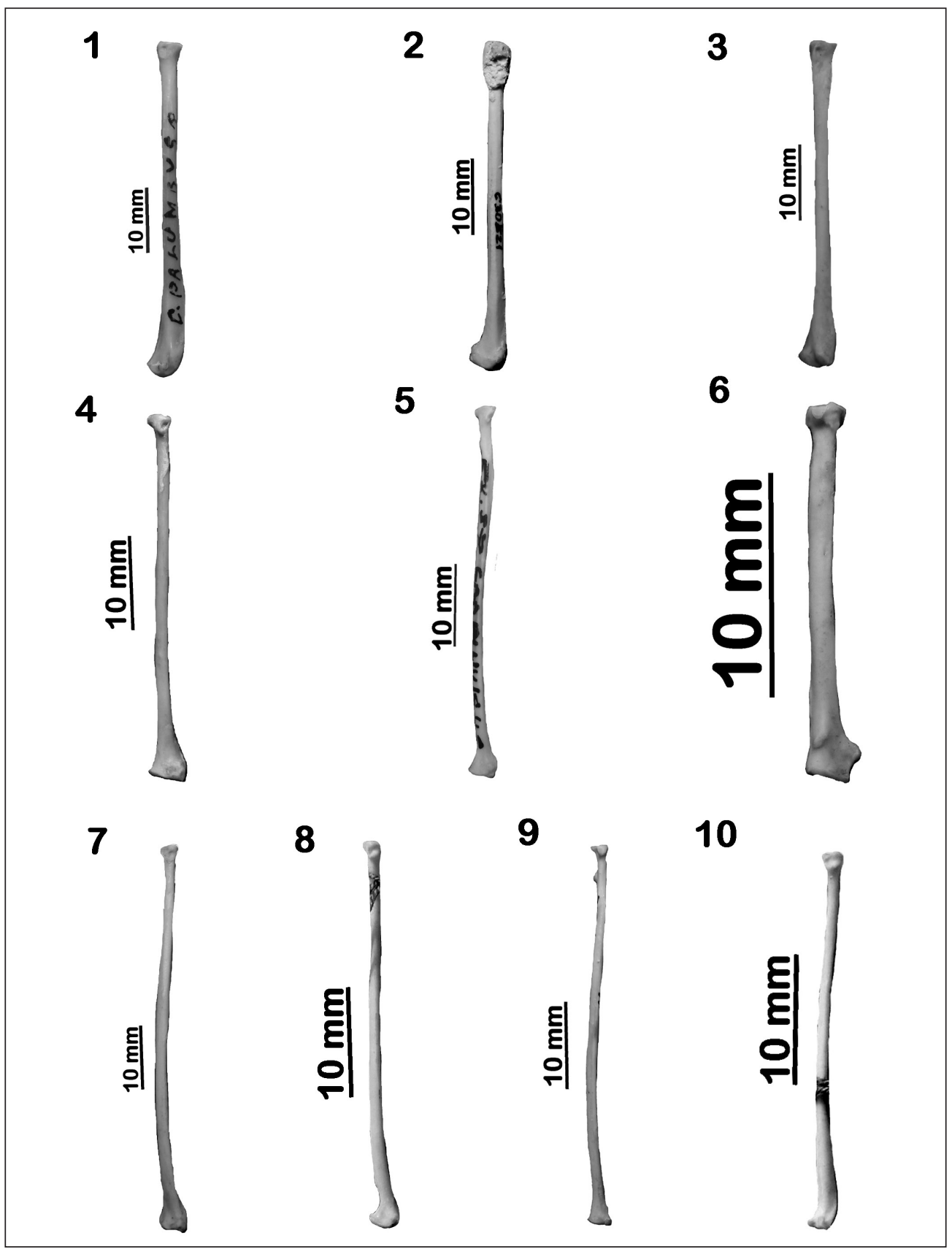

Figure 10. Left radius (dorsal aspect) - 1. Columba palumbus; 2. Streptopelia turtur; 3. Syrrhaptes paradoxus; 4. Cuculus canorus; 5. Caprimulgus europaeus; 6. Apus apus; 7. Coracias garrulus; 8. Merops apiaster; 9. Upupa epops; 10. Alcedo atthis

10. ábra Bal oldali orsócsont (háti nézet) - 1. Columba palumbus; 2. Streptopelia turtur; 3. Syrrhaptes paradoxus; 4. Cuculus canorus; 5. Caprimulgus europaeus; 6. Apus apus; 7. Coracias garrulus; 8. Merops apiaster; 9. Upupa epops; 10. Alcedo atthis 


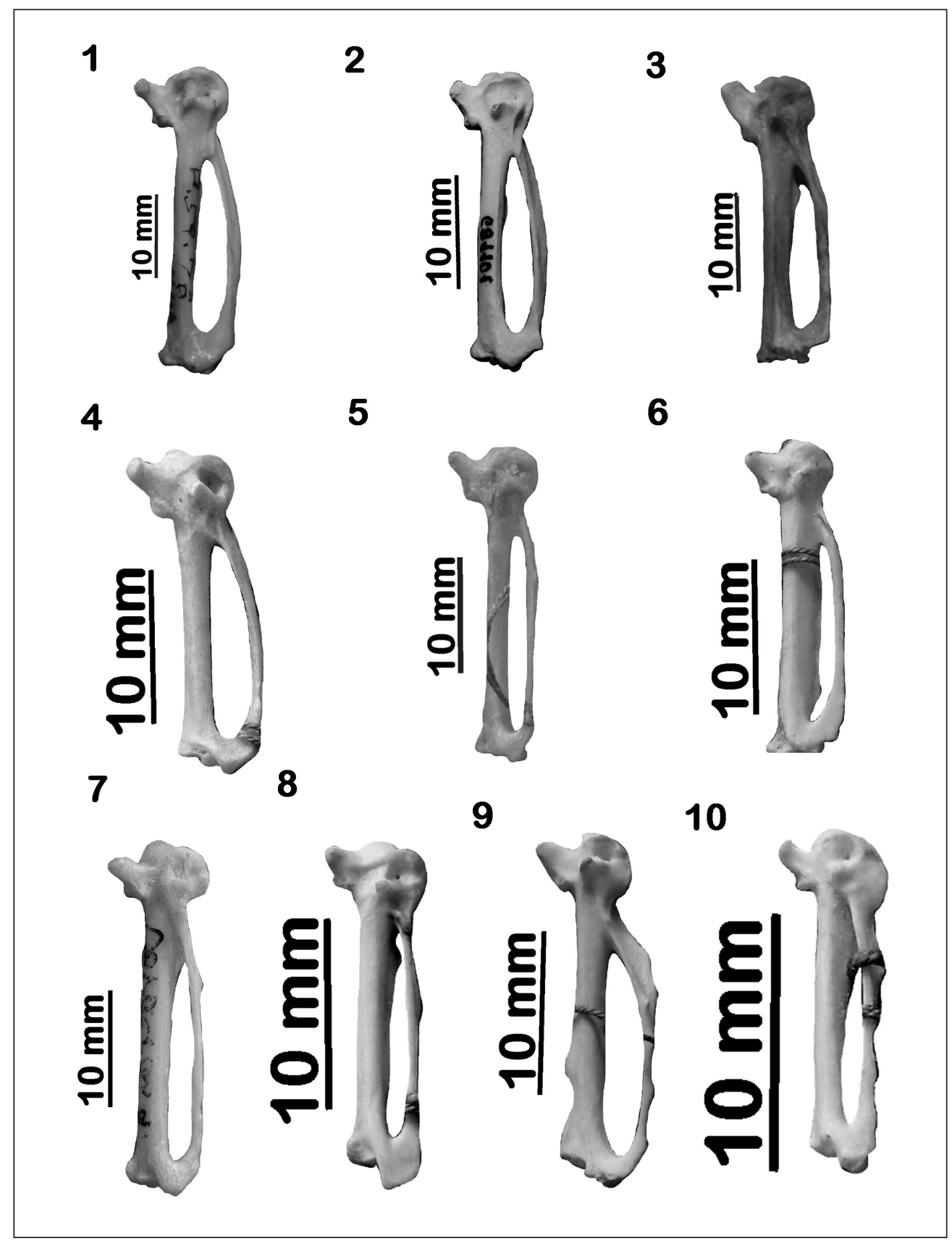

Figure 11. Left carpometacarpus (ventral aspect) - 1. Columba palumbus; 2. Streptopelia turtur; 3. Syrrhaptes paradoxus; 4. Cuculus canorus; 5. Caprimulgus europaeus; 6. Apus apus; 7. Coracias garrulus; 8. Merops apiaster; 9 . Upupa epops; 10. Alcedo atthis

11.ábra Bal oldali kézközépcsont (hasi nézet) - 1. Columba palumbus; 2. Streptopelia turtur; 3. Syrrhaptes paradoxus; 4. Cuculus canorus; 5. Caprimulgus europaeus; 6. Apus apus; 7. Coracias garrulus; 8. Merops apiaster; 9. Upupa epops; 10. Alcedo atthis 




Figure 12. Left phalanx proximalis digiti majoris (ventral aspect) - 1. Columba palumbus; 2 . Streptopelia turtur; 3. Syrrhaptes paradoxus; 4. Cuculus canorus; 5. Caprimulgus europaeus; 6. Apus apus; 7. Coracias garrulus; 8. Merops apiaster; 9 . Upupa epops; 10. Alcedo atthis

12. ábra Bal oldali kézujjperc (I. ujjperc, 2. ujj, hasi nézet) - 1. Columba palumbus; 2. Streptopelia turtur; 3. Syrrhaptes paradoxus; 4. Cuculus canorus; 5. Caprimulgus europaeus; 6. Apus apus; 7. Coracias garrulus; 8. Merops apiaster; 9. Upupa epops; 10. Alcedo atthis 


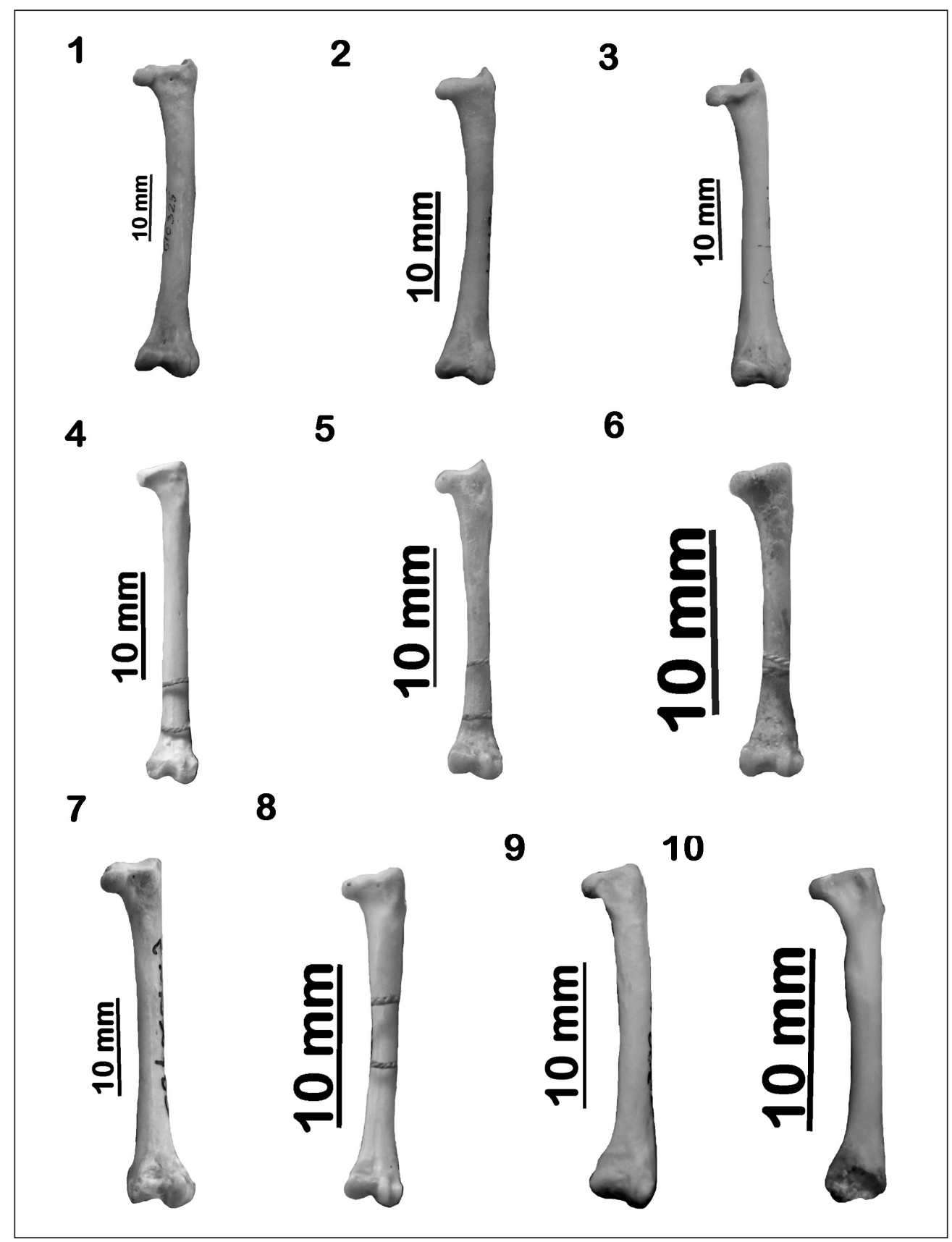

Figure 13. Right femur (caudal aspect) - 1. Columba palumbus; 2. Streptopelia turtur; 3. Syrrhaptes paradoxus; 4. Cuculus canorus; 5. Caprimulgus europaeus; 6. Apus apus; 7. Coracias garrulus; 8. Merops apiaster; 9. Upupa epops; 10. Alcedo atthis

13. ábra Jobb oldali combcsont (háti nézet) - 1. Columba palumbus; 2. Streptopelia turtur; 3 . Syrrhaptes paradoxus; 4. Cuculus canorus; 5. Caprimulgus europaeus; 6. Apus apus; 7. Coracias garruIus; 8. Merops apiaster; 9. Upupa epops; 10. Alcedo atthis 


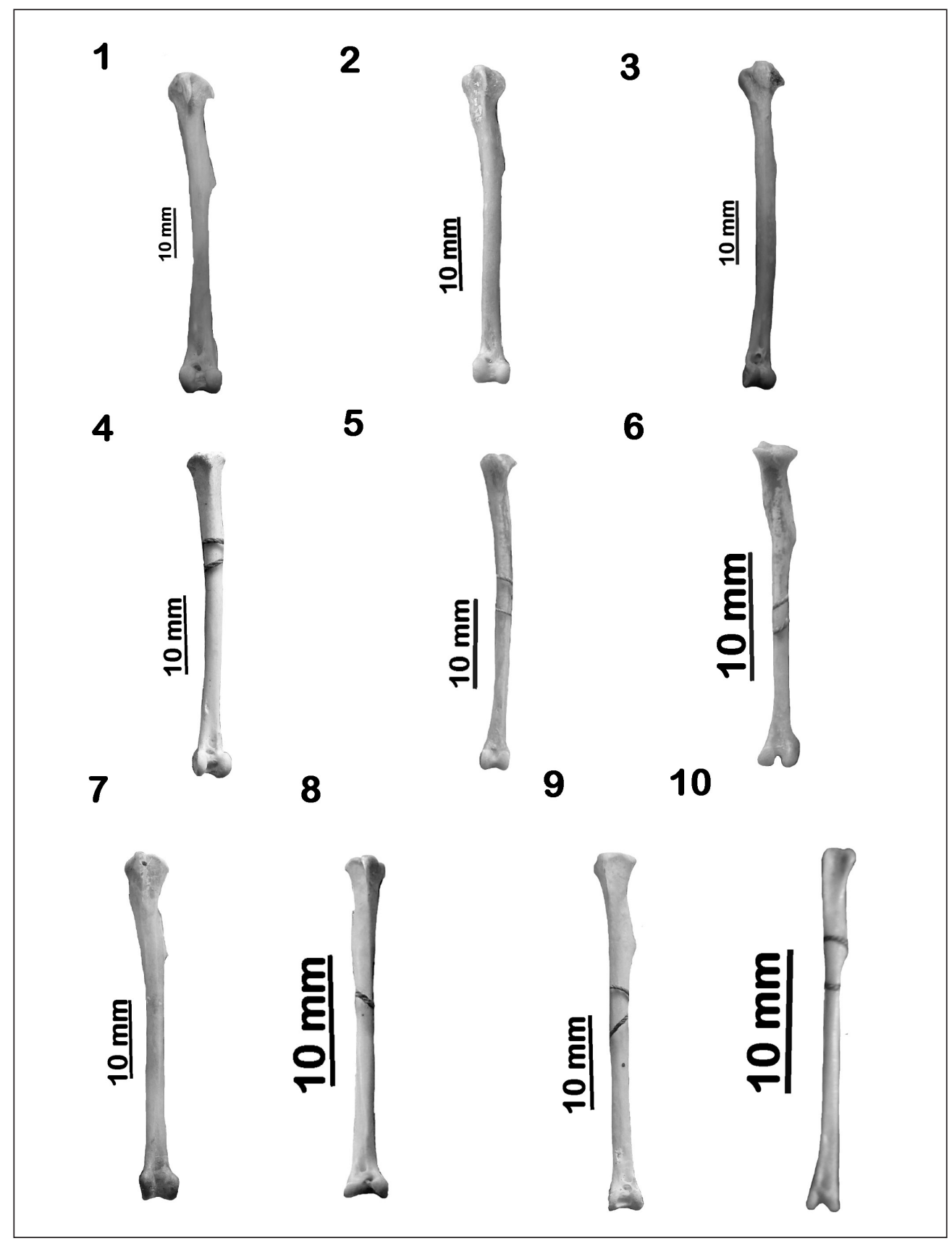

Figure 14. Left tibiotarsus (cranial aspect) - 1. Columba palumbus; 2. Streptopelia turtur; 3. Syrrhaptes paradoxus; 4. Cuculus canorus; 5. Caprimulgus europaeus; 6. Apus apus; 7. Coracias garrulus; 8. Merops apiaster; 9. Upupa epops; 10. Alcedo atthis

14. ábra Bal oldali lábszárcsont (hasi nézet) -1. Columba palumbus; 2. Streptopelia turtur; 3. Syrrhaptes paradoxus; 4. Cuculus canorus; 5. Caprimulgus europaeus; 6. Apus apus; 7. Coracias garrulus; 8. Merops apiaster; 9. Upupa epops; 10. Alcedo atthis 




Figure 15. Left tarsometatarsus (dorsal aspect) - 1. Columba palumbus; 2. Streptopelia turtur; 3. Syrrhaptes paradoxus; 4. Cuculus canorus; 5. Caprimulgus europaeus; 6. Apus apus; 7. Coracias garrulus; 8. Merops apiaster; 9. Upupa epops; 10. Alcedo atthis

15. ábra Bal oldali csüd (háti nézet) - 1. Columba palumbus; 2. Streptopelia turtur; 3. Syrrhaptes paradoxus; 4. Cuculus canorus; 5. Caprimulgus europaeus; 6. Apus apus; 7. Coracias garrulus; 8. Merops apiaster; 9. Upupa epops; 10. Alcedo atthis 


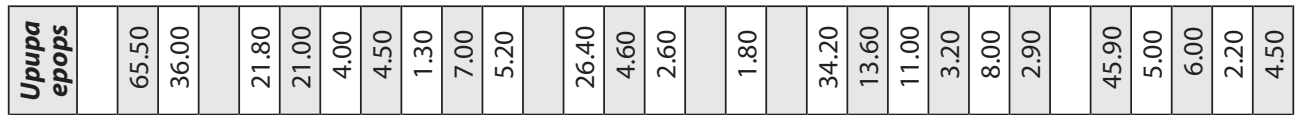

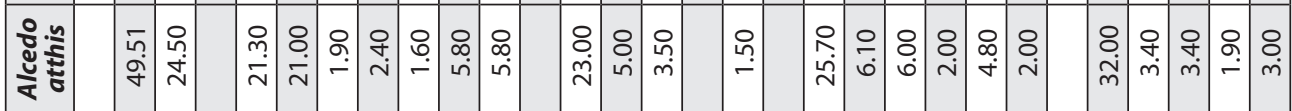

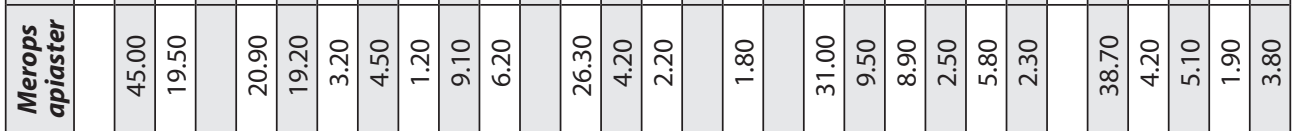



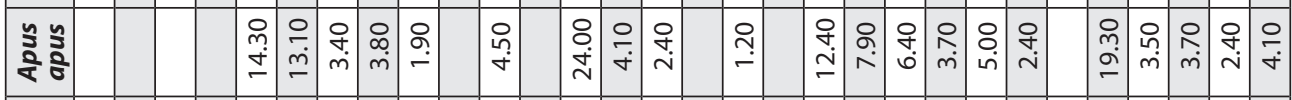

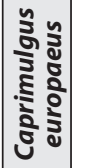

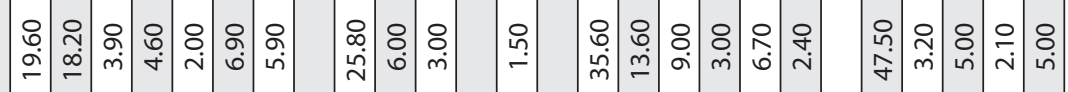

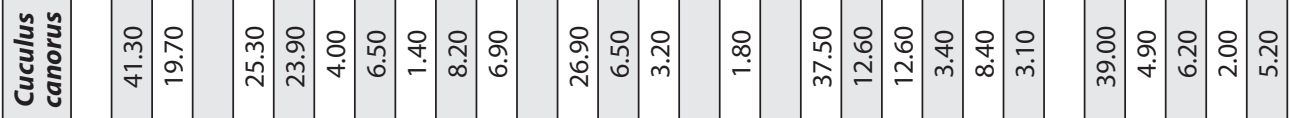

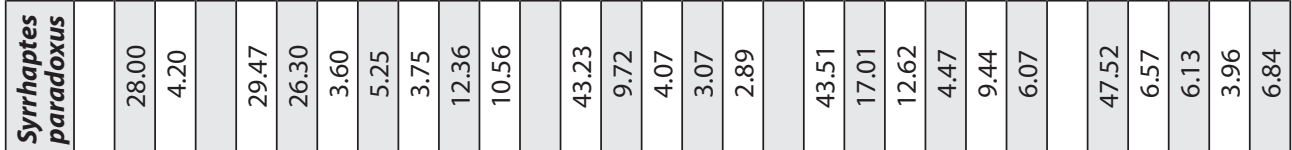

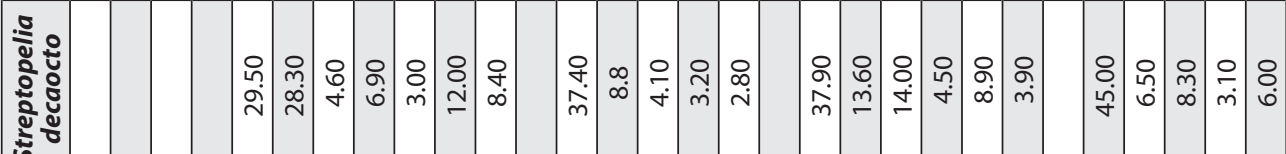

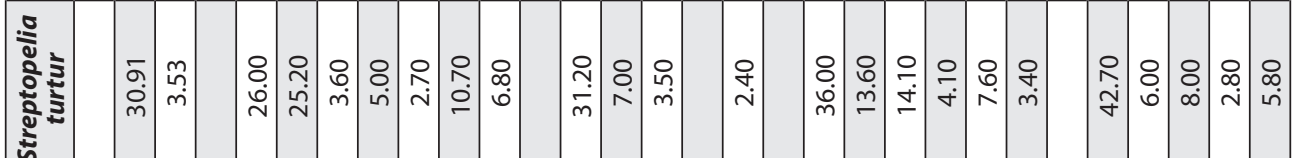

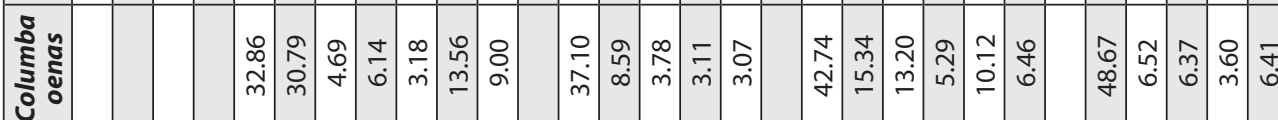

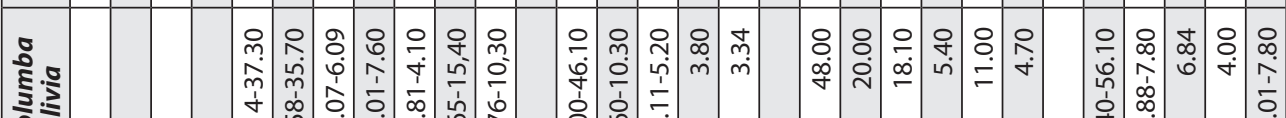

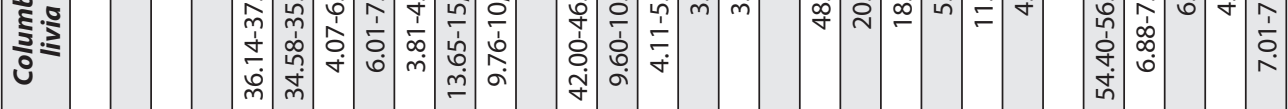



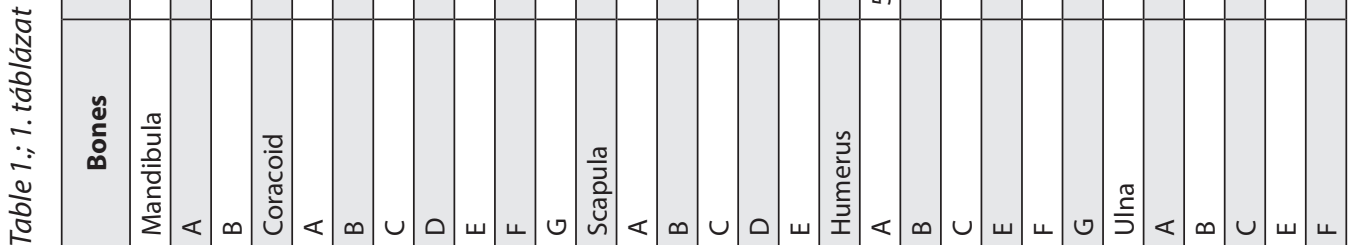




\begin{tabular}{|c|c|c|c|c|c|c|c|c|c|c|c|c|c|c|c|c|c|c|c|c|c|c|}
\hline 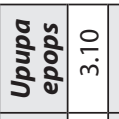 & 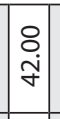 & ^ُ & ㄱำ & & $\mid \begin{array}{c}0 \\
\dot{\sim}\end{array}$ & $\begin{array}{c}8 \\
\stackrel{0}{0} \\
-\end{array}$ & 5 & గُ & hn & 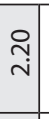 & $\left|\begin{array}{c}0 \\
0 \\
o\end{array}\right|$ & సి & & & 立 & & 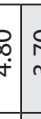 & ָָ & 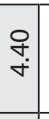 & $\begin{array}{c}\infty \\
\dot{m} \\
\dot{m}\end{array}$ & & 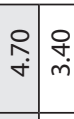 \\
\hline 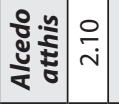 & $\begin{array}{l}0 \\
\vdots \\
\grave{ }\end{array}$ & 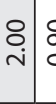 & \begin{tabular}{l}
8 \\
\hdashline \\
0
\end{tabular} & & $\mid \begin{array}{c}\stackrel{0}{m} \\
\stackrel{m}{-}\end{array}$ & 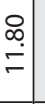 & ֵֵ: & 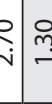 & 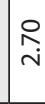 & 声 & $\begin{array}{l}\text { 어 } \\
0\end{array}$ & 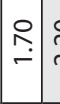 & & 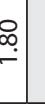 & 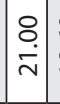 & : & ? & & $\begin{array}{l}\stackrel{8}{p} \\
\dot{m}\end{array}$ & & & 吕 \\
\hline 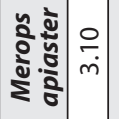 & $\begin{array}{c}0 \\
\infty \\
\stackrel{\rho}{m} \\
m\end{array}$ & 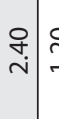 & 요 & Sh & $\left|\begin{array}{l}0 \\
0 \\
\infty \\
0\end{array}\right|$ & 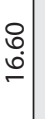 & 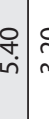 & 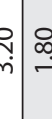 & $\stackrel{\circ}{\stackrel{f}{f}}$ & $\frac{O}{\grave{N}}$ & 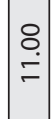 & 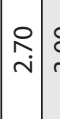 & 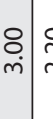 & స્. & 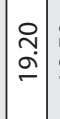 & 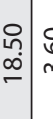 & & $\stackrel{\circ}{\rightarrow}$ & $\begin{array}{l}q \\
\dot{p} \\
\dot{m}\end{array}$ & 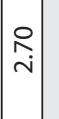 & 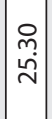 & \\
\hline 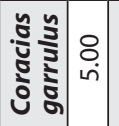 & $\begin{array}{l}\stackrel{8}{\dot{b}} \\
\end{array}$ & 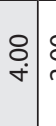 & 8 & & 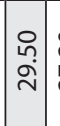 & 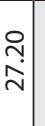 & $\stackrel{R}{?}$ & ?ִ. & ㅇ. & $\left|\begin{array}{l}0 \\
h \\
m \\
m\end{array}\right|$ & $\begin{array}{l}8 \\
\dot{\leftrightarrow} \\
\stackrel{1}{2}\end{array}$ & $\begin{array}{l}\stackrel{\leftrightarrow}{+} \\
\dot{\tau}\end{array}$ & ৪ & $\begin{array}{l}8 \\
\\
+ \\
\end{array}$ & $\frac{\stackrel{p}{m}}{m}$ & ஃ্ণ & ه. & f & ? & \begin{tabular}{|l}
8 \\
in
\end{tabular} & $\mid \begin{array}{l}0 \\
\tilde{y} \\
\tilde{\gamma}\end{array}$ & \\
\hline
\end{tabular}

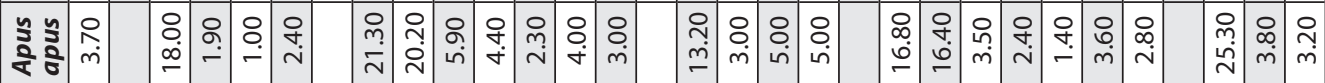

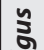

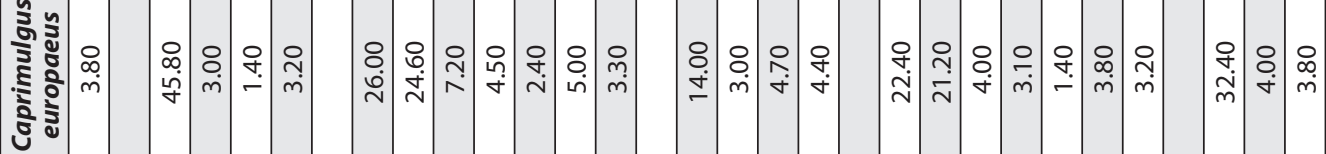

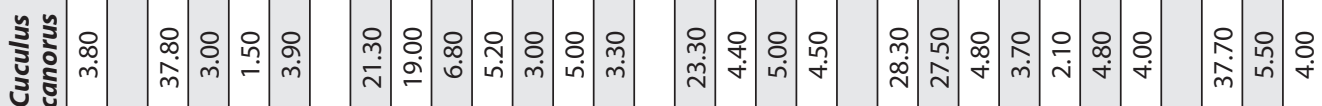

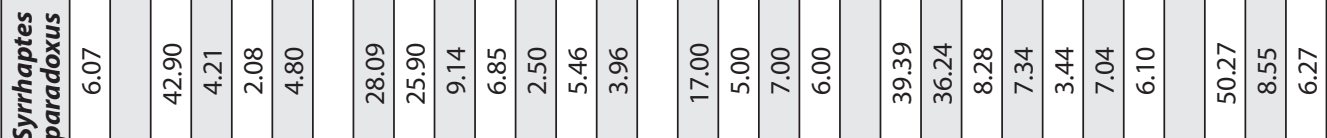
ำ

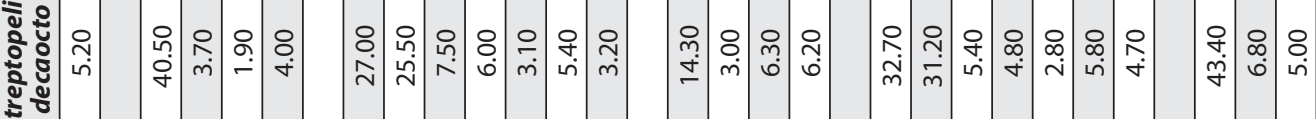
n



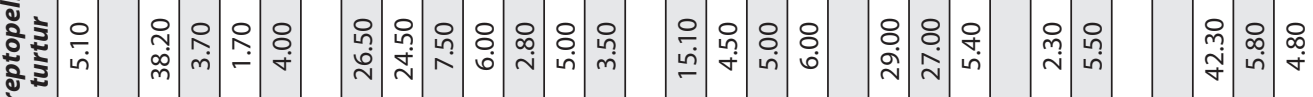
空

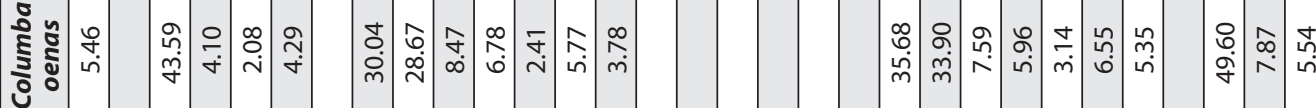

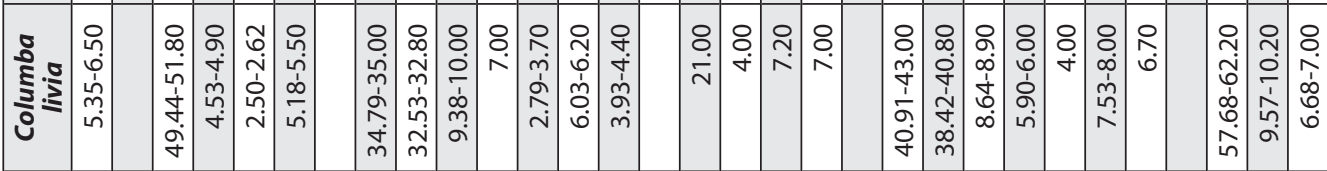

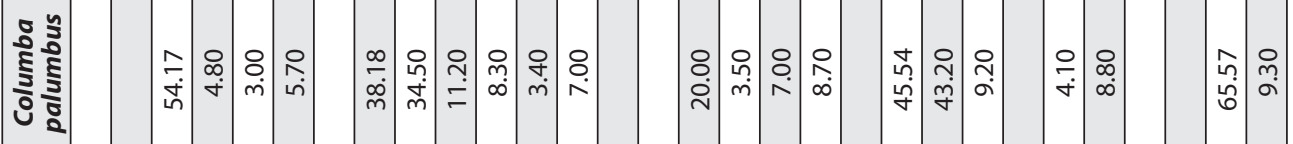




\section{References}

Ballmann, P. 1976. Fossile Vögel aus dem Neogen der Halbinsel Gargano (Italien), zweiter Tei [Birds from the Neogene of the Gargano peninsula (Italy), Part II.]. - Scripta Geologica 38: 1-59. (in German)

Baumel, J. J., King, A. S., Lucas, A. M., Breazile, J. E. \& Evans, H. E. 1979. Nomina Anatomica Avium. - Academic Press, London

Bökönyi, S. 1984. Animal husbandry and hunting in Tác-Gorsium. The vertebrate fauna of the Roman town in Pannonia. - Akadémiai Kiadó, Budapest

Bökönyi, S. \& Jánossy, D. 1965. Szubfosszilis vadmadár leletek Magyarországon (Subfossile Wildvogelfunde aus Ungarn) [Subfossil wild bird remains from Hungary]. - Vertebrata Hungarica 7: 85-99. (in Hungarian and German)

Čapek, V. 1917. A püspökfürdői preglaciális madárfauna [The Preglaciale bird fauna from Püspökfürdö]. - Barlangkutatás 5: 66-74. (in Hungarian)

Gál, E. 2002. Avifauna pleistocena a Romaniei [Pleistocene bird faunas of Romania]. - (Unpublied C.Sc dissertation) Universitatea din Bucureşti, Facultatea de Geologie București (in Romanian)

Gál, E. 2004. New evidence of fowling and poultry keeping in Pannonia, Dacia and Moesia during the period of the Roman Empire. - In: Gruppe, G. \& Peters, J. (eds.) Feathers, grit and symbolism. Birds and humans in the Ancient Old and New Worlds. - Proceedings of the $5^{\text {th }}$ Meeting of the ICAZ Bird Working Group, Munich, Germany, 26-30. July 2004. - Documenta Archaeobiologiae 3. Verlag Marie Leidorf GmbH. Rahden/ Westf., pp. 301-316.

Gál, E. 2005. Animal remains from archaeological excavations in North-Eastern Hungary. - In: Gál, E., Juhász, I. \& Sümegi, P. (eds.) Environmental archaeology in North-Eastern Hungary. - Varia Archaeologica Hungarica 19: 139-174.

Gál, E. 2007a The Neolitic avifauna of Hungary within the context of the Carpathian Basin. - Antaeus 27: 273286.

Gál, E. 2007b Fowling in lowlands. Neolithic and Chalcolithic bird exploitation in South-East-Romania and the Great Hungarian Plain. - Archaeolinqua, Series Minor 24., Budapest

Gilbert, B. M., Martin, L. D. \& Savage, H. G. 1981. Avian Osteology. - 709 Kearney, Laramie, Wyoming

Hamar, M. \& Csák, K. 1969. Contribuţii la cunoaşterea faunei de vertebrate pleistocene din Dealul Burzău (com. Rîpa, jud. Bihor) - jung Würm [Contributions to the knowledge pf pleistocene vertebrate fauna in Burzău Hill (Rîpa, Bihor County) - jung Würm]. - Studii şi cercetări biologice, Seria Zoologie 21(6): 425. (in Romanian)

Harrison, C. J. O. 1982. Cuculiform, piciform and passeriform birds in the Lower Eocene of England. - Tertiary Research 4: 71-81.

Harrison, C. J. O. \& Walker, C. A. 1977. Birds of the British Lower Eocene. - Tertiary Researchs 3: 1-32.

Jánossy, D. 1971. Die erste nachweis einer Kalt-Moustérien Vertebratenfauna in Ungarn (Tokod-Nagyberek, Kom. Komárom) [The first evidence of a Cold-Mousterian vertebrate fauna in Hungary (Tokod-Nagyberek, Kom. Komárom)]. - Vertebrata Hungarica 12: 103-110. (in German)

Jánossy, D. 1974. Die mittelpleistozäne Vogelfauna von Hundsheim (Niederösterreich) [The Middle Pleistocene avifauna of Hundsheim (Lower Austria)]. - Sitzungsberichte der Österreichischen Akademie der Wissen-schaften, Mathematisch-Naturwissenschftliche Klasse, Abteilung I. 182: 211-257. (in German)

Jánossy, D. 1977. Plio-pleistocene bird remains from the Carpathian Basin. III. Strigiformes, Falconiformes, Caprimulgiformes, Apodiformes. - Aquila 84: 9-36.

Jánossy, D. 1979a A magyarországi pleisztocén tagolása a gerinces faunák alapján [Layout of the Hungarian Pleistocene based on the Vertebrate fauna]. - Akadémiai Kiadó, Budapest (in Hungarian)

Jánossy, D. 1979b Plio-pleistocene bird remains from the Carpathian Basin. V. Podicipediformes, Ciconiiformes, Otidiformes, Columbiformes, Piciformes. - Aquila 86: 19-33.

Jánossy, D. 1980. Plio-pleistocene bird remains from the Carpathian Basin. VI. Systematical and Geographical Catalogue. - Aquila 87: 9-22.

Jánossy, D. 1985. Wildvogelreste aus archaeologischen Grabungen in Ungarn (Neoliticum bis Mittelalter) [Wild bird remains from archaeological excavations in Hungary (from the Neolithicum to the Middle Ages)]. Fragmenta Mineralogica et Paleontologica 12: 67-103. (in German)

Jánossy, D. 1986. Pleistocene Vertebrate faunas of Hungary. - Akadémiai Kiadó, Budapest \& Elsevier, Amsterdam Jánossy, D. 1991. Late Miocene bird remains from Polgárdi (W-Hungary). - Aquila 98: 13-35.

Jánossy, D. 1992. Lower Pleistocene Bird Remains from Beremend (S-Hungary, Loc. 15. and 16.). - Aquila 99: 9-25. 
Jánossy, D. 1996 Lower Pleistocene vertebrate faunas from the localities 16 and 17 of Beremend (southern Hungary). - Fragmenta Mineralogica et Paleontologica 18: 91-102.

Jánossy, D. \& Vörös, I. 1987. Die mittelpleistozäne Fauna der Höhle des Hungaria-Berges bei Dorog (Gerecse Gebirge, Ungarn) [The Middle Pleistocene fauna of the cave of the Hungaria Mountain near Dorog (Gerecse Mountains, Hungary)]. - Fragmenta Mineralogica et Paleontologica 13: 97-110. (in German)

Kessler, E. 1974. Date noi asupra avifaunei fosile a Dealului Burzău - Râpa [New data on the fossil avifauna of Burzau Hill - Râpa]. - Nymphaea 2: 159-167. (in Romanian)

Kessler, E. 1975. Contribuţii noi la studiul avifaunei fosile de la Betfia, jud. Bihor [New contributions to fossil avifauna from Betfia, Bihor County]. - Nymphaea 3: 53-59 (in Romanian)

Kessler, E. 1977. Avifauna postglaciară de la Vadu Crişului, jud. Bihor [Postglaciar Avifauna from Vadu Crisului, Bihor County]. -Tibiscus: 255-260 (in Romanian)

Kessler, E. 1982. Avifauna fosilă şi subfosilă a Munţilor Apuseni [Fossil and subfossil bird fauna from Apuseni Mountains]. - Nymphaea 10: 171-181. (in Romanian)

Kessler, J. 2009. Új eredmények a Kárpát-medence neogén és negyedidőszaki madárvilágához II. rész [New results with regard to the Neogene and Quaternary avifauna of the Carpathian Basin, Part II.]. - Földtani Közlöny 139(3): 251-271. (in Hungarian with English Summary)

Kessler, J. 2010. Új eredmények a Kárpát-medence neogén és negyedidőszaki madárvilágához III. rész [New results with regard to the neogene and Quaternary avifauna of the Carpathian Basin, Part III.]. - Földtani Közlöny 140(1): 53-72. (in Hungarian with English Summary)

Kessler, J. 2013. A Kárpát-medence madárvilágának őslénytani kézikönyve [Paleontological handbook of birdlife in the Carpathian Basin]. - Könyvmühely, Miskolc (in Hungarian)

Kessler, E. \& Gál, E. 1997. Resturi fosile şi subfosile de păsări din Banat [Fossil and subfossil bird remains in Banat]. - Analele Banatului - Ştiinţele Naturii 3: 141-144. (in Romanian with English Summary)

Kessler, J. \& Hír, J. 2012. Észak-Magyarország madárvilága a miocénben II. rész [The avifauna in North Hungary during the Miocene, Part II.]. - Földtani Közlöny 141(2): 149-168. (in Hungarian with English Summary)

Kessler, E. \& Venczel, M. 2009. Bird remains from the Middle Miocene of Subpiatră (W-Romania). - Nymphaea, Folia Naturae Bihariae XXXVI: 27-36.

Kordos, L. 1984. A bodajki Rigó-lyuk újholocén kitöltésének vizsgálata [Investigating the Holocene filling of the Bodajk-Rigó Hole]. - Folia Musei Historico-Naturalis Bakonyensis 3: 31-42. (in Hungarian)

Kormos, T. 1913. Kleinere Mitteilungen aus dem ungarischen Pleistozän [Small releases from the Hungarian Pleistocene]. - Centralblatt für Mineralogie, Geologie und Palaontologie 1913: 13-17. (in German)

Kormos, T. 1914. Az 1913. évben végzett ásatásaim eredményei [The results of the excavations carried in the year 1913]. - A Magyar Királyi Földtani Intézet 1913. évi jelentése, pp. 498-505., 531-540. (in Hungarian)

Lambrecht, K. 1912. A borsodi Bükk fossilis madarai (Fossile Vögel des Borsoder Bükkgebirges) [Fossil birds of the Bükk Mountains from Borsod]. - Aquila 19: 270-287. (in Hungarian and German)

Lambrecht, K. 1913. Neueren Daten zur fossilen Ornis unseren Höhlen [Newer fossil ornis data for our caves]. Barlangkutatás 1: 173. (in German)

Lambrecht, K. 1915. Fossilis nagy fülesbagoly (Bubo maximus Flemm.) és egyéb madármaradványok a magyarországi pleistocénből [Fossil's Great Eagle Owl (Bubo maximus Flemm.) and other bird remains in Hungarian Pleistocene]. - Aquila 22: 177-187. (in Hungarian)

Lambrecht, K. 1916. Az első magyar preglaciális madárfauna - Die erste ungarische praglaziale Vogelfauna [The first Hungarian Preglaciale bird fauna]. - Aquila 22: 165-172. (in Hungarian and German)

Lambrecht, K. 1933. Handbuch der Palaeornithologie [Handbook of Palaeornithology]. - Gebrüder Borntraeger, Berlin (in German)

Malez, V. 1984. Paleornitološki ostaci iz kvartarnih naslaga nekih spilja Hrvatske i Slovenije [Paleornithological remains from the Quaternary Sediments of some Croatian and Slovenian caves]. - Deveti jugoslavenski speleoloski kongres, Zbornik predavanja, pp. 711-719. (in Croatian)

Malez-Bačić, V. 1979. Pleistocenska ornitofauna iz Šandalje u Istri te njezino stratigrafsko i paleoekološko značenje [Pleistocene bird fauna from Šandalja in Istria and its stratigraphic and paleoecological significance]. - Palaeontologia Jugoslavica 21: 1-46. (in Croatian)

Mayr, G. 1999. Caprimulgiform birds from the Middle Eocene of Messel (Hessen, Germany). - Journal of Vertebrate Paleontology 19: 521-532. DOI: 10.1080/02724634.1999.10011162

Mayr, G. 2003. A new Eocene swift-like bird with a peculiar feathering. - Ibis 145: 382-391. DOI: 10.1046/j.1474919X.2003.00168.x 
Mayr, G. 2004. New specimens of Hassiavis laticauda (Aves: Cypselomorphae) and Quasisyndactylus longibrachis (Aves: Alcediniformes) from the Middle Eocene of Messel, Germany. - Courier Forschungsinstitut Senckenberg 252: 23-28.

Mayr, G. 2005. A new cypselomorph bird from the Middle Eocene of Germany and the early diversification of avian aerial insectivores. - Condor 107(2): 342-352.

Mayr, G. \& Daniels, M. 2001. A new short-legged landbird from the early Eocene of Wyoming and contemporaneous European sites. - Acta Paleontologica Polonica 46: 393-402.

Mayr, G. \& Mourer-Chauviré, C. 2000. Rollers (Aves: Coraciiformes s. s.) from the Middle Eocene of Messel (Germany) and the Upper Eocene of the Quercy (France). - Journal of Vertebrate Paleontology 20(3): 533546. DOI: 10.1671/0272-4634(2000)020[0533:RACSSF]2.0.CO;2

Mayr, G. \& Mourer-Chauviré, C. 2005. A specimen of Parvicuculus Harrison \& Walker 1977 (Aves: Parvicuculidae) from the early Eocene of France. - Bulletin of the British Ornithologists' Club 125(4): 299-304.

Meyer, H. 1865. Fossile Vögel von Radoboy und Oehningen [Fossil birds of Radoboy and Oehningen]. - Palaeontographica 14: 125-131. (in German)

Milne-Edwards, A. 1869-1871. Recherches anatomiques et paléontologiques pour servir àl'histoire des oiseaux fossiles de la France, Vol. 2. [Anatomical and paleontological research to serve the history of fossil birds of France, Vol. 2.]. - Paris: V. Masson (in French)

Mlíkovskỳ, J. 1997. Taxonomic identity of Fringilla radoboyensis von Meyer 1865 (Aves) from the middle Miocene of Croatia. - Annalen des Naturhistorischen Museums in Wien (A) 98: 143-149.

Mlíkovskỳ, J. 2002. Cenozoic birds of the World, Part I.: Europe. - Ninox Press, Praha

Olson, S. L. 1985. The fossil record of birds. - Avian Biology 7: 80-252.

Pike-Tay, A., Bartosiewicz, L., Gál, E. \& Whitle, A. 2004. Body part representation and seasonility: sheep/ goat, bird and fish remains from Early Neolithic Ecsegfalva 23 SE Hungary. - Journal of Taphonomy 2(4): 221-246.

Portis, A. 1889. Gli ornitoliti del Valdarno superiore e di alcune altre località plioceniche di Toscana [The ornitolites of the upper Valdarno and some other Pliocene localities of Tuscany]. - Memorie Regio Istituto di Studi Superiori e Practici (Firenze) 1889: 1-20. (in Italian)

Soergel, E. 1966. Die Vogelreste [The Bird Remains]. - In: Ehrenberg, K. (ed.) Die Teufels-oder Fuck-senlucke bei Eggenburg (NÖ) [The Devil or Fuck senlucke at Eggenburg (NA)]. - Denkschriften der Mathematisch-Naturwissenschftliche Klasse der Österreichischen Akademie der Wissenschaften, pp. 93-107. (in German)

Tyrberg, T. 1998. Pleistocene birds of the Palearctic: a catalogue. - Publications of the Nuttall Ornithological Club, No. 27. Cambridge

Von den Driesch, A. 1976. A guide to the measurements of animal bones from archaeological sites. - Peabody Museum Bulletin 1.

Vojintsven'skyj, M. A 1967. Iskopaemaja ornitofauna Krimea [The fossil avifauna of Crimea]. - Prirodnaja Obstanovka i Fauni Prollogo 3: 3-76 (in Russian)

Wettstein, O. V. \& Mühlhofer, F. 1938. Die Fauna der Höhle von Merkenstein in N-Ö [The fauna of the Merkenstein Cave in North Austria]. - Archiv Naturgeschichte, new series 7(4): 514-558. (in German)

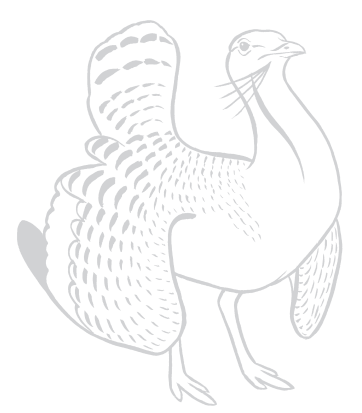

